\title{
Heavy Metals in Mine-Tailing Soil Mixtures Cultivated with Ricinus communis $\mathrm{L}$.
}

\author{
Elizabeth González-Terreros ${ }^{1}$, Víctor Manuel Ruíz-Valdiviezo ${ }^{2 *}$, \\ Alejandro Galván-Velázquez ${ }^{1}$, Marina Olivia Franco-Hernández ${ }^{3}$, \\ Marco Luna-Guido', Luc Dendooven ${ }^{1}$ \\ ${ }^{1}$ Laboratory of Soil Ecology, ABACUS, Cinvestav, México City, México \\ ${ }^{2}$ Laboratory of Molecular Biology, Instituto Tecnológico de Tuxtla Gutiérrez, Tecnológico Nacional de México, \\ Tuxtla Gutiérrez, Chiapas, México \\ ${ }^{3}$ Department of Chemistry, Unidad Profesional Interdisciplinaria de Biotecnología-IPN (UPIBI), \\ Barrio la Laguna Ticomán, Mexico
}

Received: 10 August 2017

Accepted: 22 October 2017

\begin{abstract}
Ricinus communis L. was found to vegetate mine tailings with high concentrations of $\mathrm{Al}\left(4,456 \mathrm{mg} \mathrm{kg}^{-1}\right)$, As $\left(3,473 \mathrm{mg} \mathrm{kg}^{-1}\right), \mathrm{Cd}\left(120 \mathrm{mg} \mathrm{kg}^{-1}\right), \mathrm{Cr}\left(14 \mathrm{mg} \mathrm{kg}^{-1}\right), \mathrm{Cu}\left(1,147 \mathrm{mg} \mathrm{kg}^{-1}\right)$, and $\mathrm{Pb}\left(910 \mathrm{mg} \mathrm{kg}^{-1}\right)$. We investigated how this plant responded to increased heavy metal concentrations by mixing mine tailing at $0 \%, 50 \%, 70 \%$, and $100 \%$ with soil at $100 \%, 50 \%, 30 \%$, and $0 \%$, while metal concentrations in the rhizosphere, roots, and aboveground parts of $R$. communis were monitored. Ricinus communis shoots were $19 \%$ smaller and roots $8 \%$ in soil mixed with an equal amount of mine tailings compared to plants cultivated in soil and $33 \%$ and $54 \%$, respectively, when cultivated in mine tailings. The ratio of $\mathrm{As}, \mathrm{Cd}, \mathrm{Cu}$, and $\mathrm{Pb}$ in the aboveground plant parts to the concentration in soil remained $<0.12$, while that of the roots $<0.25$. The As concentration was $35 \%$ lower in the bulk soil than in the rhizosphere. We found that $R$. communis growth was inhibited strongly when cultivated in mine tailings, but less so when mixed with soil, and metals did not accumulate in the roots and aboveground plant parts. These characteristics make $R$. communis ideal to vegetate metal-contaminated soil, thereby reducing the environmental hazards of mine tailings.
\end{abstract}

Keywords: aboveground plant parts, bulk soil, exclusion or accumulation of metals, rhizosphere

\section{Introduction}

Mining activities generate large amounts of metalrich waste materials and are considered a major cause of soil contamination [1]. In Mexico, mining for gold,

*e-mail: bioqvic@hotmail.com silver, and copper started 500 years ago, which has created huge amounts of mine waste, or tailings [2]. These tailings contaminate soil, subsoil, aquifers, surface and ground water, the atmosphere, flora, and fauna. Drinking water is contaminated and animals left to graze accumulate the heavy metals taken up by plants [3-4]. This dispersion of these heavy metals in the environment and their bioaccumulation poses a serious risk to humans [4]. 
There are plants that resist high concentrations of heavy metals in the soil [5-6]. Some plants incorporate the metals, but are not affected metabolically by them, while others exclude them [7]. The efficiency of these processes depends on the type of plant, soil characteristics, and microbiota in the rhizosphere [8]. Consequently, some plants can grow on heavily contaminated mine tailings [9]. In a previous study, Ortega et al. [10] found species of the Euphorbiaceae family, e.g. Acalypha monostachya Cav., Euphorbia sp. L., Jatropha sp. L., and Ricinus communis L. growing on mine tailings in Zimapan (Hidalgo, Mexico). These plants, particularly Ricinus communis, grew in soils with high concentrations of heavy metals, such as $\mathrm{Al}, \mathrm{As}, \mathrm{Cd}$, $\mathrm{CO}, \mathrm{Cr}, \mathrm{Cu}$, and $\mathrm{Pb}[10]$. These characteristics would make them ideal to vegetate mine tailings, thereby limiting the environmental hazards of mine waste.

Ricinus communis is a plant adapted to a wide range of climates and can be found now in most tropical and subtropical parts of the world [11], and is cultivated in countries such as India, China, Brazil, Argentina, Thailand, and the Philippines [12-13]. Ricinus communis is a multipurpose crop of interest because of its commercial importance as a non-food tree for biodiesel production [14-15], and unique biochemistry and valuable biomaterials, such as, castor oil, ricinoleic acid, ricinoleyl-sulfate, lithium grease (lithium hydroxystearate), 10-undecylenic acid, and 11-aminoun-decanoic acid [16]. It is used widely in traditional medicine and has been used against constipation, stomach disorders, swelling fever, and scorpion stings [17-18].
Several studies have found that $R$. communis grows in metal-contaminated soil with a potential for phytoremediation [14]. It is not known, however, how much the growth of Ricinus communis is affected when cultivated in mine tailings with high concentrations of heavy metals and if the plant accumulates or excludes them. Therefore, in this study $R$. communis plantlets were cultivated in mixtures of soil $(100 \%, 50 \%, 30 \%$, and $0 \%$ ) and mine tailings $(0 \%, 50 \%, 70 \%$, and $100 \%)$, while plant growth was monitored and the roots and shoots were analyzed for metals after 90, 120, and 270 days.

\section{Material and Methods}

\section{Sampling Mine Tailings and Soil Collection}

Mine tailing No. $9\left(20^{\circ} 49^{\prime} 9^{\prime \prime} \mathrm{N}, 99^{\circ} 22^{\prime} 46^{\prime \prime} \mathrm{W}\right)$ at the San Francisco Mine in Zimapan (state of Hidalgo, Mexico) was sampled (Fig. 1). Three $400 \mathrm{~m}^{2}$ plots were outlined and the top $20 \mathrm{~cm}$ layer was spade-sampled 20 times. The 20 samples taken in each plot were pooled so that 3 samples were obtained, each of approximately $150 \mathrm{~kg}$. The collected mine tailings were transported to the laboratory and characterized (Table 1). The mine tailing sampling procedure is schematized in supplementary Fig. 1.

A soil was sampled at Cinvestav, Mexico D.F. (S1: 19³0'42”N, 997'49”W; S2: 19³0'41”N, 997'46”W and S3: 19'30'38'N, 99 $\left.7^{\circ} 48^{\prime \prime} \mathrm{W}\right)$. Three $400 \mathrm{~m}^{2}$ plots were outlined and the $0-15$ top soil layer was
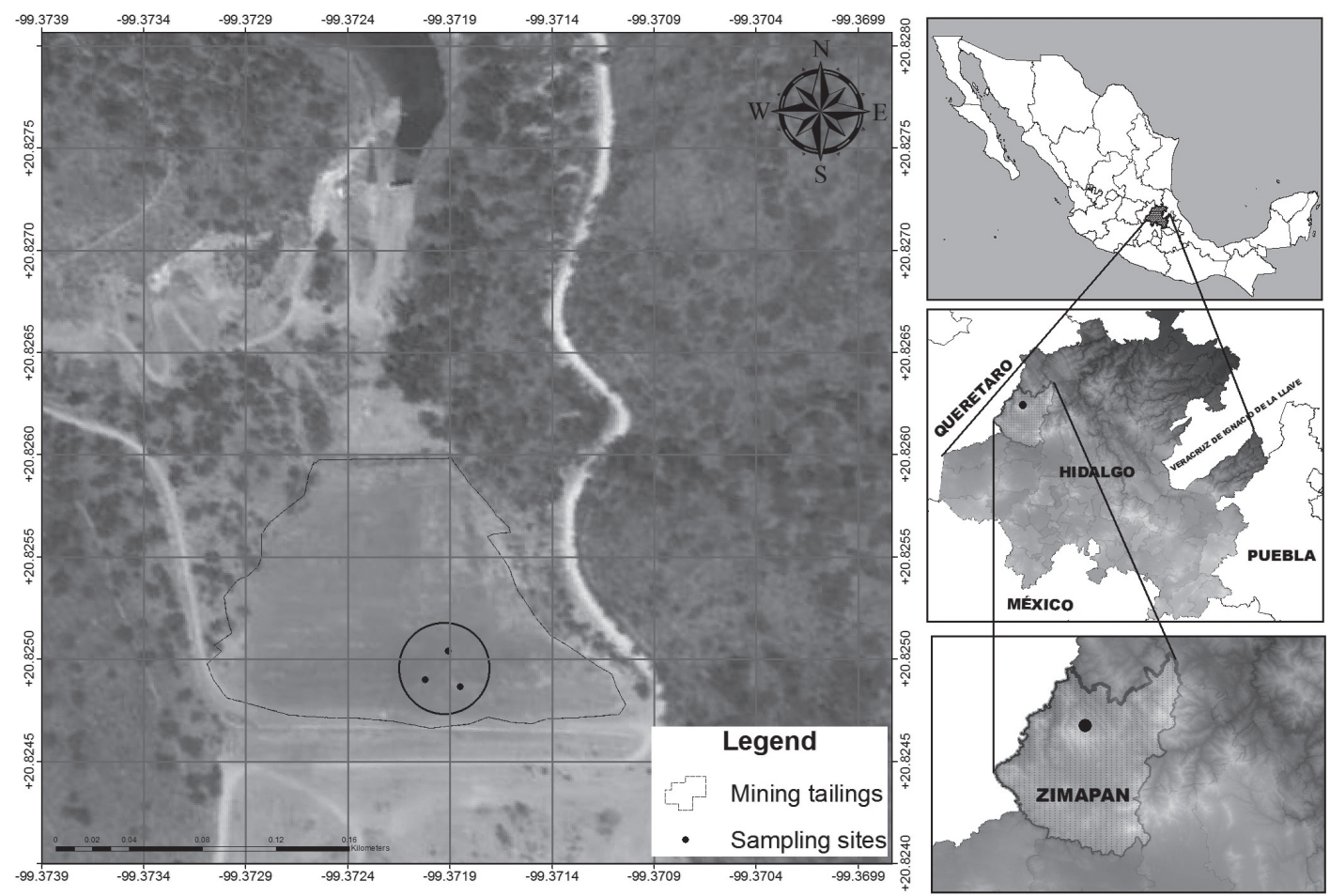

Fig 1. Sampling Sites final. 
Table 1. Characteristics of soil, soil mixed with $50 \%$ mine tailings, $30 \%$ mine tailings, and $100 \%$ mine tailings at the onset of the experiment.

\begin{tabular}{|c|c|c|c|c|c|c|c|c|}
\hline & & & & & & \multicolumn{3}{|c|}{ Particle size distribution } \\
\hline & $E C^{f}$ & & $\mathrm{C}_{\text {org }}{ }^{\mathrm{g}}$ & $\mathrm{N}_{\text {tot }}{ }^{\mathrm{h}}$ & $\mathrm{WHC}^{\mathrm{i}}$ & Clay & Loam & Sand \\
\hline Mixture $^{\mathrm{e}}$ & $\left.(\mathrm{dS} \mathrm{m})^{-1}\right)$ & $\mathrm{pH}$ & \multicolumn{6}{|c|}{ ( $\mathrm{g} \mathrm{kg}^{-1}$ soil) } \\
\hline A & $1.55^{\mathrm{j}} \mathrm{b}^{\mathrm{k}}$ & $8.9 \mathrm{a}$ & $8.53 \mathrm{a}$ & $1.02 \mathrm{a}$ & 540 & $420 \mathrm{a}$ & $270 \mathrm{a}$ & $310 \mathrm{~b}$ \\
\hline B & $2.75 \mathrm{ab}$ & $8.4 \mathrm{ab}$ & $8.05 \mathrm{a}$ & $0.54 \mathrm{bc}$ & 520 & $120 \mathrm{~b}$ & $110 \mathrm{~b}$ & $770 \mathrm{a}$ \\
\hline $\mathrm{C}$ & $3.78 \mathrm{a}$ & $8.4 \mathrm{ab}$ & $9.17 \mathrm{a}$ & $0.30 \mathrm{c}$ & 520 & $50 \mathrm{~b}$ & $80 \mathrm{~b}$ & $870 \mathrm{a}$ \\
\hline $\mathrm{D}$ & $3.03 \mathrm{ab}$ & $8.0 \mathrm{~b}$ & $4.86 \mathrm{a}$ & $0.13 \mathrm{~cd}$ & 0 & $40 \mathrm{~b}$ & $60 \mathrm{~b}$ & $900 \mathrm{a}$ \\
\hline$F$ value & 10.74 & 9.59 & 0.21 & 28.86 & 1.35 & 24.89 & 15.02 & 57.65 \\
\hline$P$ value & 0.008 & 0.011 & 0.889 & $<0.001$ & 0.344 & $<0.001$ & 0.003 & $<0.001$ \\
\hline $\mathrm{MSD}^{1}$ & 1.68 & 0.6 & 16.71 & 0.38 & 860 & 200 & 140 & 200 \\
\hline
\end{tabular}

${ }^{\mathrm{e}}$ Mixture A: $100 \%$ soil, Mixture B: $50 \%$ soil and 50\% mine tailing, Mixture C: $30 \%$ soil and $70 \%$ mine tailing, Mixture D: $100 \%$ mine tailing, ${ }^{\mathrm{f}}$ EC: Electrolytic conductivity, ${ }^{\mathrm{g}} \mathrm{C}_{\text {org }}$ : Organic carbon, ${ }^{\mathrm{h}} \mathrm{N}_{\text {tot }}$ : Total nitrogen, ${ }^{\mathrm{i}} \mathrm{WHC}$ : Water holding capacity, ${ }^{\mathrm{j}}$ Mean of three plots $(n=3),{ }^{\mathrm{k}}$ Values with the same capital letter are not significantly different between the mixtures (i.e. within the lines), ${ }^{1}$ MSD: Minimum significant difference at $P<0.05$ (SAS Institute1989)

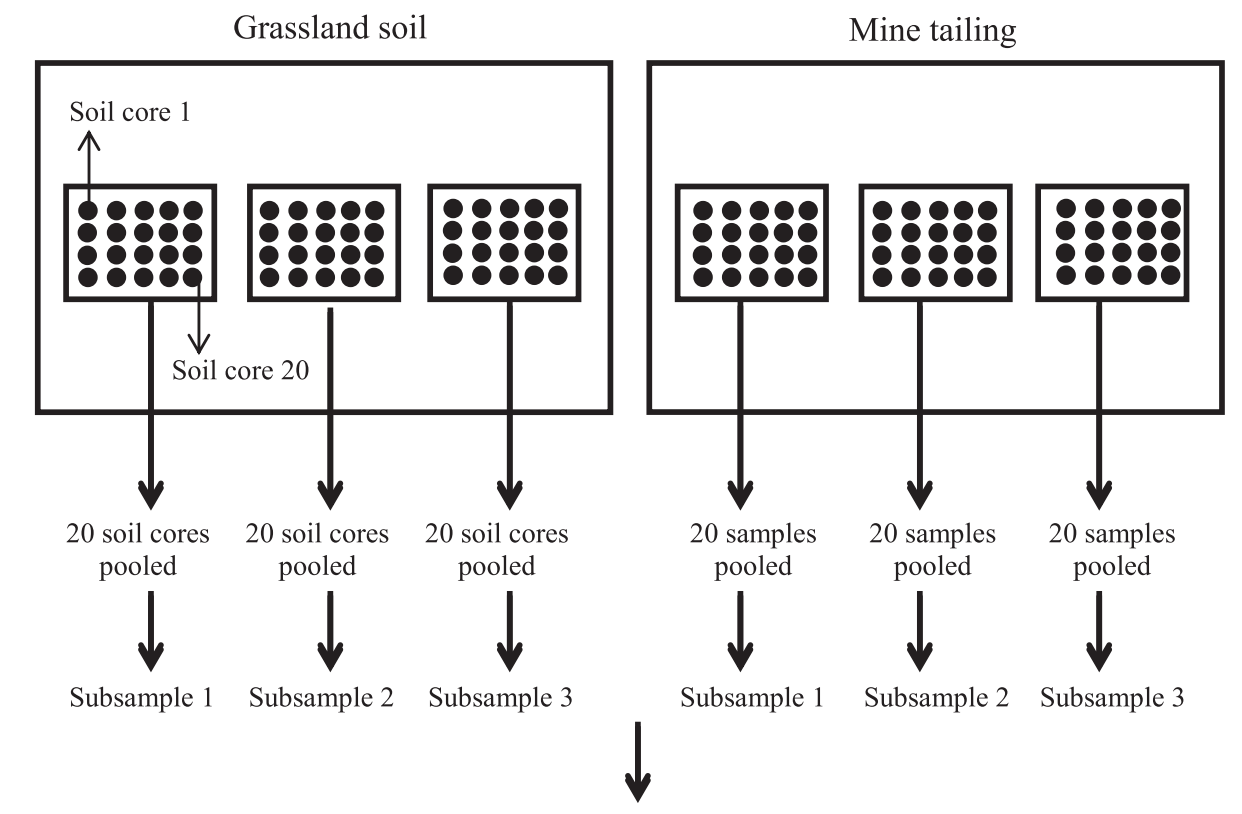

A subsample of soil was combined with a subsample of the mine tailing to give four treatments and characterized:

1. Three subsamples of $100 \%$ soil:

2. Three subsamples of $50 \%$ soil and $50 \%$ mine tailing

3. Three subsamples of $30 \%$ soil and $70 \%$ mine tailing

4. Three subsamples of $100 \%$ mine tailing

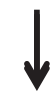

Nine soil columns of each subsample $(n=3)$ and each treatment $(n=4)$ were left uncultivated Nine soil columns of each subsample $(n=3)$ and each treatment $(n=4)$ were planted with Ricinus communis

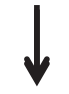

The columns were kept in a greenhouse for 9 months and growth of $R$. communis monitored After 3, 6 and 9 months three columns were selected at random from each treatment $(n=4)$ each subsample $(n=3)$ left uncultivated or cultivated with $R$. communis

The uncultivated soil, the bulk and the rhizsopheric soil and the roots and above ground parts of $R$. communis were characterized

Supplementary Fig. 1 Sampling procedure at the mine tailing, collection of the soil, mixture of soil and mine tailing and treatments applied. 
Table 2. Characteristics of Ricinus communis L. cultivated in different mixtures of soil and mine tailings in a greenhouse.

\begin{tabular}{|c|c|c|c|c|c|c|}
\hline & \multicolumn{5}{|c|}{ Leaves } & \multicolumn{2}{c|}{ Shoot } & Root \\
\hline & & Length & Width & \multicolumn{2}{|c|}{$(\mathrm{cm})$} \\
\hline Mixture $^{\mathrm{e}}$ & Number & \multicolumn{5}{|c|}{$61.4 \mathrm{a}$} \\
\hline $\mathrm{A}$ & $16.9^{\mathrm{f}} \mathrm{a}^{\mathrm{g}}$ & $8.1 \mathrm{a}$ & $9.0 \mathrm{a}$ & $32.9 \mathrm{a}$ & $26.6 \mathrm{ab}$ & $56.4 \mathrm{a}$ \\
\hline $\mathrm{B}$ & $6.4 \mathrm{~b}$ & $6.7 \mathrm{ab}$ & $7.6 \mathrm{ab}$ & $7.6 \mathrm{ab}$ & $28.2 \mathrm{ab}$ & $48.7 \mathrm{a}$ \\
\hline $\mathrm{C}$ & $6.2 \mathrm{~b}$ & $7.0 \mathrm{a}$ & $6.6 \mathrm{~b}$ & $22.1 \mathrm{~b}$ & $28.0 \mathrm{~b}$ \\
\hline $\mathrm{D}$ & $5.7^{\mathrm{h}} \mathrm{b}$ & 7.87 & 6.61 & 4.36 & 4.63 & 9.32 \\
\hline$F$ value & $<0.001$ & $<0.001$ & 0.007 & 0.005 & $<0.001$ \\
\hline$P$ value & 8.2 & 1.5 & 1.8 & 7.3 & 14.9 \\
\hline MSD
\end{tabular}

${ }^{\mathrm{e}}$ Mixture A: $100 \%$ soil, Mixture B: $50 \%$ soil and 50\% mine tailing, Mixture C: $30 \%$ soil and $70 \%$ mine tailing, Mixture D: $100 \%$ mine tailing, ${ }^{\mathrm{f}}$ Mean of 27 plants $(n=27)$, i.e. three sampling points, i.e. 3, 6 and 9 months, three plots and three plants per plot,

$\mathrm{g}$ Values with the same capital letter are not significantly different between the mixtures (i.e. within the columns),

${ }^{\text {h }}$ mean of 6 surviving plants, ${ }^{i}$ MSD: Minimum significant difference at $P<0.05$ (SAS Institute, 1989)

spade-sampled 20 times. The 20 samples from each plot were pooled so that 3 different soil samples were obtained of approximately $150 \mathrm{~kg}$. The soil was $2 \mathrm{~mm}$-sieved and characterized (Table 1). The soil sampling procedure is schematized in supplementary Fig. 1.

\section{Cultivation of Ricinus communis in the Greenhouse}

Seeds of $R$. communis were collected along the edge of the Rio de los Remedios in the State of México (México). The seeds were placed in small pots with soil and the emerged plantlets collected after 20 days. Four different treatments were applied in the experiment. In the first treatment, $R$. communis was cultivated in $100 \%$ soil. In a second treatment mine tailings were mixed with an equal amount of soil, in a third treatment soil $(30 \%)$ was mixed with mine tailings $(70 \%)$, and in a fourth treatment plants were cultivated in $100 \%$ mine tailings. Growth of $R$. communis in the $100 \%$ mine tailings was much slower than in the other treatments and most of the plants died. The surviving plants were collected after 9 months and included in the analysis.

The cultivation procedure of $R$. communis is schematized in supplementary Fig. 1. A sub-sample of soil of one of the three plots was mixed with one sample of the mine tailing so that 3 different replicates were obtained and these 3 replicates $(n=3)$ were used in each treatment $(n=4)$.

The experiment was conducted in a greenhouse. Polyvinyl chloride (PVC) tubes (length $50 \mathrm{~cm}$ and diameter $(\varnothing) 16 \mathrm{~cm}$ ) were filled at the bottom with $7 \mathrm{~cm}$ gravel topped with $3 \mathrm{~cm}$ sand [19]. A total of $6.5 \mathrm{~kg}$ of the different mixtures of soil and mine tailings were transferred to the PVC tubes. As such, a layer of
$30 \mathrm{~cm}$ soil was obtained. Nine $R$. communis plantlets were planted separately in each of the 3 replicates of the 4 treatments. As such, 27 R. communis plants were used in each treatment. Every 7 days, $500 \mathrm{ml}$ water was added to each column. The temperature, relative humidity, and light intensity in the greenhouse were monitored.

After 3, 6, and 9 months, 3 columns were selected at random from each replicate and each treatment, and the plant and soil were removed from the PVC tubes. As such, 9 plants and soil samples were obtained. The soil was separated from the roots and the soil attached to the roots was brushed off and collected [20]. Root and shoot length and number, and width and length of the leaves were determined. The roots, leaves, and shoots were washed with distilled water, and the roots were separated from the shoots and analyzed separately for total metals.

\section{Analysis of Plant and Soil}

The shoots + leaves, roots, and soil were analyzed as described by Franco-Hernández, (2010). The heavy and total metals were measured by inductively coupled plasma-optical emission spectrometry (ICP-OES) spectrometer (4300DV-Perkin Elmer, USA). Montana soil standard reference materials were obtained from the National Institute of Standards and Technology (USA) and served as control. Quality control was done for each batch of 50 samples. The plastic material used for analysis of metals were treated with $2 \% \mathrm{HNO}_{3}$ before use. The bulk soil samples were analyzed for total carbon and nitrogen, electrolytic conductivity (EC), $\mathrm{pH}$, clay content, and water-holding capacity (WHC) as described by Aguilar-Chavez et al. [21] (Table 1). All chemicals used in this study were of laboratory grade and purchased at Sigma Aldrich (St. Louis, Missouri, USA). 


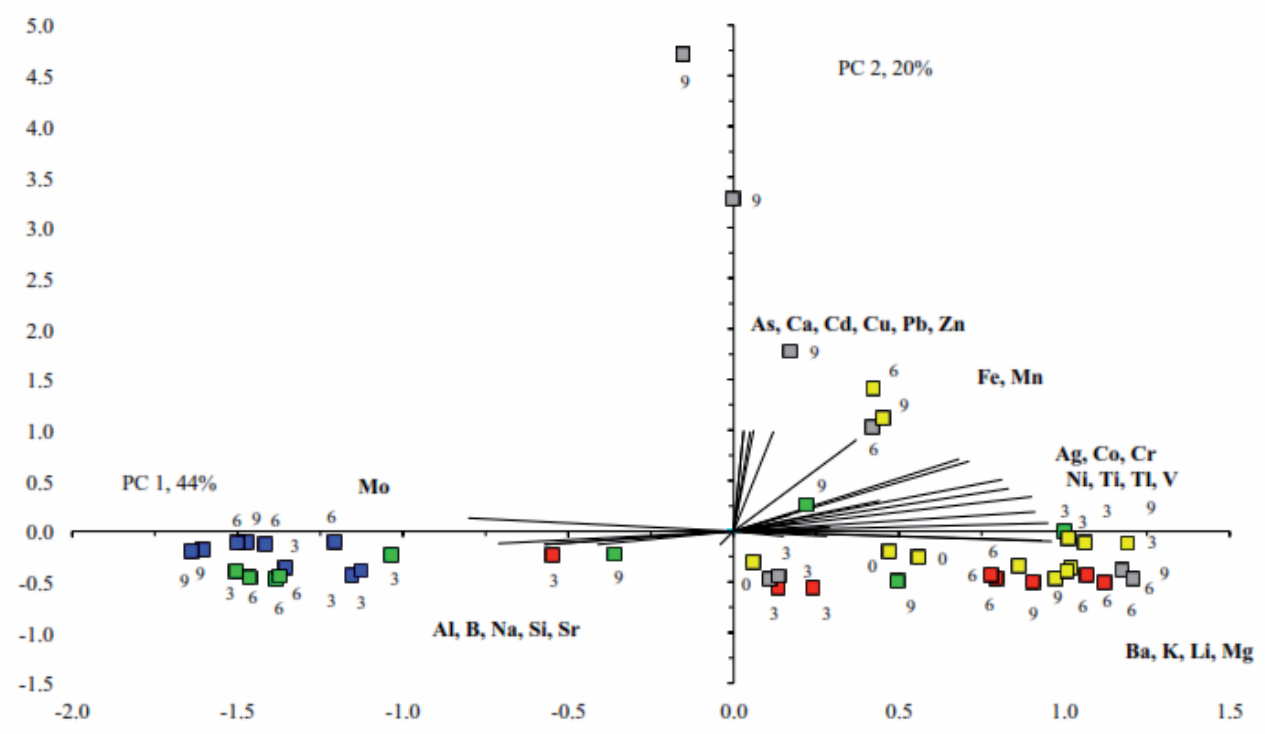

Fig. 2. Principal component analysis with the concentration of the different elements measured in the roots ( $\square$ ) and aboveground parts of

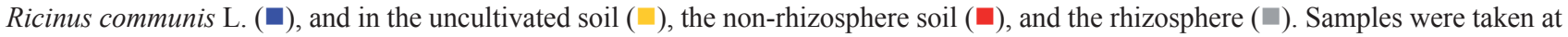
the onset of the experiment (0) and after 3, 6, or 9 months. Principal component 1 (PC1) explained 44\% of the variation and PC2 $20 \%$.

\section{Statistical Analysis}

Significant differences between the soil characteristics and the plant characteristics as a result of the different treatments were determined by analysis of variance (ANOVA) and based on the minimum significant difference using the general linear model procedure (PROC GLM) [22]. This procedure can be used for an analysis of variance (ANOVA) for unbalanced data, i.e., when data are missing. Significant differences between the metal concentrations in the uncultivated, bulk, and rhizospheric soil and the aboveground plant parts and the roots as a result of the different treatments were determined by ANOVA and based on the least significant difference using the general linear model procedure (PROC GLM) [22].

\section{Results}

\section{Characteristics of Soil and Mine Tailings}

The soil was characterized by an alkaline $\mathrm{pH}$ of 8.9 and an organic $\mathrm{C}$ content of $8.53 \mathrm{~g} \mathrm{~kg}^{-1}$ dry soil (Table 1). The total $\mathrm{N}$ content of the clayey soil was $1.02 \mathrm{~g} \mathrm{~kg}^{-1}$ dry soil and the EC $1.55 \mathrm{dS} \mathrm{m}^{-1}$, while the WHC was $540 \mathrm{~g} \mathrm{~kg}^{-1}$. The mine tailings had $\mathrm{pH} 8.0$ and EC $3.03 \mathrm{dS} \mathrm{m}^{-1}$. The total $\mathrm{N}$ content of $0.13 \mathrm{~g} \mathrm{~kg}^{-1}$ was low compared to the total $\mathrm{C}$ content of $4.86 \mathrm{~g} \mathrm{~kg}^{-1}$ resulting in a C-to-N ratio of 37 . The mine tailings were sandy, but did not retain water so it was impossible to determine the WHC. The characteristics of the mixture (50\% soil and 50\% mine tailings, and 30\% soil and 70\% mine tailings) were between those found in the soil or mine tailings.
The organic C content in soil, the mine tailings, and the mixtures of both cultivated with $R$. communis was significantly higher after 9 months than at the onset of the experiment, but no differences were found in the other soil characteristics (data not shown). After 9 months, the organic $\mathrm{C}$ content had increased 2.8 times in the soil cultivated with $R$. communis and the mixture of $50 \%$ soil with $50 \%$ mine tailings, 2.5 times in the mixture of $30 \%$ soil with $70 \%$ mine tailings and 1.2 times in the mine tailings compared to the onset of the experiment.

\section{Growth of $R$. communis}

Ricinus communis grew best in soil and its development was inhibited strongly when cultivated in the mine tailings (Table 2). Most of the R. communis plants cultivated in the mine tailings died and only 6 of the 27 plants survived for 9 months. The root length of $R$. communis was significantly reduced when cultivated in the mine tailings compared to plants cultivated in soil or soil mixed with mine tailings $(p<0.05)$. The number of leaves was significantly higher when plants were cultivated in soil compared to plants cultivated in the mine tailings or mine tailings mixed with soil $(p<0.001)$. Shoot length and the width and length of the leaves of $R$. communis were significantly lower when cultivated in mine tailings compared to plants cultivated in soil $(p<0.01)$.

\section{Metal Concentrations when Ricinus communis was Cultivated in $100 \%$ Soil}

The concentrations of $\mathrm{As}, \mathrm{Cd}, \mathrm{Co}, \mathrm{Cr}, \mathrm{Cu}$, and $\mathrm{Pb}$ were higher in the rhizosphere than in the 
Supplementary Table 1. Metal concentrations in bulk soil, the rhizosphere, roots, and aboveground plant material of Ricinus communis cultivated in soil, soil mixed with $50 \%$ of mine tailings, $30 \%$ of mine tailings, and $100 \%$ mine tailings and kept in a greenhouse for 270 days.

\begin{tabular}{|c|c|c|c|c|c|c|}
\hline \multicolumn{7}{|c|}{ A. Uncultivated soil } \\
\hline \multirow{2}{*}{ Metal } & $\mathrm{A}^{\mathrm{e}}$ & $\mathrm{B}$ & $\mathrm{C}$ & $\mathrm{D}$ & \multirow{2}{*}{$\mathrm{MSD}^{\mathrm{f}}$} & \multirow{2}{*}{$P$ value } \\
\hline & \multicolumn{4}{|c|}{$\mathrm{mg} \mathrm{Kg}^{-1}$ soil } & & \\
\hline $\mathrm{Ag}$ & $3.06^{\mathrm{g}} \mathrm{a}^{\mathrm{h}}$ & $1.26 \mathrm{a}$ & $3.22 \mathrm{a}$ & $1.36^{\mathrm{i}} \mathrm{a}$ & 3.96 & 0.559 \\
\hline $\mathrm{Al}$ & $\mathrm{ND}^{\mathrm{j}}$ & ND & $437 \mathrm{a}$ & $7399 a$ & 1519 & $<0.001$ \\
\hline As & $167 \mathrm{~b}$ & $2335 \mathrm{a}$ & $2740 \mathrm{a}$ & $3274 \mathrm{a}$ & 550 & $<0.001$ \\
\hline B & $5.06 \mathrm{~b}$ & $\mathrm{ND} b$ & ND & ND & 6.04 & 0.215 \\
\hline $\mathrm{Ba}$ & $224 \mathrm{a}$ & $122 \mathrm{a}$ & $51.5 \mathrm{a}$ & $26.7 \mathrm{a}$ & 49.2 & $<0.001$ \\
\hline $\mathrm{Be}$ & $0.09 \mathrm{a}$ & $0.09 \mathrm{~b}$ & $0.11 \mathrm{~b}$ & ND & 0.24 & 0.448 \\
\hline $\mathrm{Ca}\left(\mathrm{x} 10^{3}\right)$ & $16 \mathrm{~b}$ & $47 \mathrm{ab}$ & $54 \mathrm{a}$ & $57 \mathrm{a}$ & 8.3 & $<0.001$ \\
\hline $\mathrm{Cd}$ & $5.90 \mathrm{~b}$ & $76.2 \mathrm{a}$ & $96 \mathrm{a}$ & $110 \mathrm{a}$ & 18.4 & $<0.001$ \\
\hline $\mathrm{Co}$ & $10.0 \mathrm{ab}$ & $17.5 \mathrm{a}$ & $18.5 \mathrm{a}$ & $18.0 \mathrm{~b}$ & 3.0 & $<0.001$ \\
\hline $\mathrm{Cr}$ & $24.9 \mathrm{a}$ & $26.1 \mathrm{a}$ & $21.0 \mathrm{a}$ & $15.2 \mathrm{ab}$ & 9.3 & 0.098 \\
\hline $\mathrm{Cu}$ & $66.2 \mathrm{~b}$ & $718 \mathrm{a}$ & $881 \mathrm{a}$ & $1058 \mathrm{ab}$ & 159 & $<0.001$ \\
\hline $\mathrm{Fe}\left(\mathrm{x} 10^{3}\right)$ & $21 \mathrm{a}$ & $50 \mathrm{a}$ & $54 \mathrm{a}$ & $57 \mathrm{a}$ & 8.0 & $<0.001$ \\
\hline $\mathrm{K}$ & $1459 \mathrm{a}$ & $1465 \mathrm{a}$ & $867 \mathrm{a}$ & 1929 a & 1612 & 0.704 \\
\hline $\mathrm{Li}$ & $11.4 \mathrm{a}$ & $25.0 \mathrm{a}$ & $331 \mathrm{a}$ & $5.20 \mathrm{a}$ & 570 & 0.582 \\
\hline $\mathrm{Mg}$ & $7956 \mathrm{a}$ & $5460 \mathrm{a}$ & $3582 \mathrm{ab}$ & $2583 \mathrm{a}$ & 1315 & $<0.001$ \\
\hline $\mathrm{Mn}$ & $339 \mathrm{~b}$ & $714 \mathrm{ab}$ & $709 \mathrm{ab}$ & $834 \mathrm{a}$ & 158 & $<0.001$ \\
\hline Mo & $1.05 \mathrm{~b}$ & $2.29 \mathrm{bc}$ & $3.20 \mathrm{ab}$ & $4.3 \mathrm{ab}$ & 3.0 & 0.005 \\
\hline $\mathrm{Na}$ & $929 \mathrm{a}$ & $550 \mathrm{ab}$ & $169 \mathrm{~b}$ & $183 \mathrm{~b}$ & 644 & 0.0426 \\
\hline $\mathrm{Ni}$ & $16.0 \mathrm{a}$ & $26.3 \mathrm{a}$ & $76.1 \mathrm{a}$ & $24.0 \mathrm{a}$ & 93 & 0.511 \\
\hline $\mathrm{Pb}$ & $65.2 \mathrm{~b}$ & $634 \mathrm{a}$ & $664 \mathrm{a}$ & $839 \mathrm{ab}$ & 165 & $<0.001$ \\
\hline $\mathrm{Se}$ & $2.35 \mathrm{a}$ & $1.00 \mathrm{~b}$ & $55.2 \mathrm{a}$ & ND & 93 & 0.549 \\
\hline $\mathrm{Si}$ & $283 \mathrm{a}$ & $251 \mathrm{a}$ & $92 \mathrm{~b}$ & $279 \mathrm{ab}$ & 241 & 0.281 \\
\hline $\mathrm{Sr}$ & ND & $2.07 \mathrm{a}$ & $3.23 \mathrm{a}$ & $20.3 \mathrm{~b}$ & 10.2 & 0.01 \\
\hline $\mathrm{Ti}$ & $1007 \mathrm{a}$ & $784 a$ & $600 \mathrm{a}$ & $508 \mathrm{a}$ & 183 & $<0.001$ \\
\hline $\mathrm{V}$ & $33.3 \mathrm{a}$ & $47.0 \mathrm{a}$ & $49.3 \mathrm{a}$ & $47.9 \mathrm{a}$ & 9.2 & $<0.001$ \\
\hline $\mathrm{Zn}$ & $228 \mathrm{~b}$ & $2662 \mathrm{a}$ & $3342 \mathrm{a}$ & $4142 \mathrm{a}$ & 820 & $<0.001$ \\
\hline
\end{tabular}

${ }^{\mathrm{e}} \mathrm{A}$ : $100 \%$ soil, B: Mixture of $50 \%$ soil and 50\% mine tailings, C: Mixture of 30\% soil and 70\% mine tailings, D: $100 \%$ mine tailings, ${ }^{\mathrm{f}}$ MSD: Minimum significant difference at 5\% (SAS Institute 1989), ${ }^{\mathrm{g}}$ Mean of 27 plants $(n=27)$, i.e. three sampling points, i.e. 3, 6, and 9 months, three plots and three plants per plot, ${ }^{\mathrm{h}}$ Values with the same letter are not significantly different between the mixtures (i.e. within the columns), ${ }^{\mathrm{i}}$ mean of 6 surviving plants, ${ }^{\mathrm{j}} \mathrm{ND}$ : Not detected

non-rhizospheric and uncultivated soil, and the roots and aboveground parts of $R$. communis (Suplementary Table 1). The concentrations of $\mathrm{As}, \mathrm{Cd}, \mathrm{Co}, \mathrm{Cr}, \mathrm{Cu}$, and $\mathrm{Pb}$ were lower in the aboveground parts of $R$. communis than in its roots when cultivated in $100 \%$ soil. The PCA confirmed that the metal concentrations in the aboveground parts and roots of the $R$. communis plants were clearly different from those found in uncultivated soil, the non-rhizospheric and rhizospheric soil (Fig. 2, Suplementary Table 1).

\section{Metal Concentrations when Ricinus communis} was Cultivated in 50\% Soil and 50\% Mine Tailings

The concentrations of $\mathrm{As}, \mathrm{Cd}, \mathrm{Co}, \mathrm{Cr}, \mathrm{Cu}$, and $\mathrm{Pb}$ were generally lower in the rhizosphere than in 
Supplementary Table 1 . Continued.

\begin{tabular}{|c|c|c|c|c|c|c|}
\hline \multicolumn{7}{|c|}{ B. Non Rhizosphere } \\
\hline \multirow{2}{*}{ Metal } & $\mathrm{A}^{\mathrm{e}}$ & $\mathrm{B}$ & $\mathrm{C}$ & $\mathrm{D}$ & \multirow{2}{*}{$\mathrm{MSD}^{\mathrm{f}}$} & \multirow{2}{*}{$P$ value } \\
\hline & \multicolumn{4}{|c|}{$\mathrm{mg} \mathrm{Kg}^{-1}$ soil } & & \\
\hline $\mathrm{Ag}$ & $0.09^{\mathrm{g}} \mathrm{a}^{\mathrm{h}}$ & $1.42 \mathrm{a}$ & $2.84 \mathrm{a}$ & $\mathrm{ND}^{\mathrm{j}}$ & 2.14 & $<0.001$ \\
\hline $\mathrm{Al}$ & ND & ND & ND & $3878^{\mathrm{i}} \mathrm{a}$ & ND & $<0.001$ \\
\hline As & $11.0 \mathrm{~b}$ & $2278 \mathrm{a}$ & $2768 \mathrm{a}$ & 3909 a & 886 & $<0.001$ \\
\hline $\mathrm{B}$ & $4.40 \mathrm{~b}$ & $5.30 \mathrm{~b}$ & ND & ND & 10.0 & 0.389 \\
\hline $\mathrm{Ba}$ & $183 \mathrm{ab}$ & $90.0 \mathrm{a}$ & $69.0 \mathrm{a}$ & $23.0 \mathrm{a}$ & 83.0 & $<0.001$ \\
\hline $\mathrm{Be}$ & $0.07 \mathrm{a}$ & $0.53 \mathrm{a}$ & $0.10 \mathrm{~b}$ & $0.60 \mathrm{c}$ & 0.23 & $<0.001$ \\
\hline $\mathrm{Ca}\left(\mathrm{x} 10^{3}\right)$ & $13 \mathrm{~b}$ & $51 \mathrm{a}$ & $55 \mathrm{a}$ & $63 \mathrm{a}$ & 13 & $<0.001$ \\
\hline $\mathrm{Cd}$ & $2.10 \mathrm{~b}$ & $76.4 \mathrm{a}$ & $97.1 \mathrm{a}$ & $131 \mathrm{a}$ & 31.0 & 0.08 \\
\hline Co & $9.00 \mathrm{ab}$ & $16.3 \mathrm{a}$ & $18.1 \mathrm{a}$ & $25.0 \mathrm{a}$ & 5.9 & $<0.001$ \\
\hline $\mathrm{Cr}$ & $25.1 \mathrm{a}$ & $24.9 \mathrm{a}$ & $24.1 \mathrm{a}$ & $22.9 \mathrm{a}$ & 12 & 0.986 \\
\hline $\mathrm{Cu}$ & $24.1 \mathrm{~b}$ & $718 \mathrm{a}$ & $917 \mathrm{a}$ & $1162 \mathrm{a}$ & 272 & $<0.001$ \\
\hline $\mathrm{Fe}\left(\mathrm{x} 10^{3}\right)$ & $18 \mathrm{ab}$ & $51 \mathrm{a}$ & $53 \mathrm{a}$ & $61 \mathrm{a}$ & 12 & $<0.001$ \\
\hline $\mathrm{K}$ & ND & $247 \mathrm{~b}$ & $142 \mathrm{~b}$ & $751 \mathrm{~b}$ & 859 & 0.236 \\
\hline $\mathrm{Li}$ & ND & ND & ND & $6 \mathrm{a}$ & 1 & $<0.001$ \\
\hline $\mathrm{Mg}$ & $8118 \mathrm{a}$ & $5089 \mathrm{a}$ & $4085 \mathrm{ab}$ & $2621 \mathrm{a}$ & 2407 & $<0.001$ \\
\hline $\mathrm{Mn}$ & $270 \mathrm{~b}$ & $754 a$ & $810 \mathrm{a}$ & $883 \mathrm{a}$ & 212 & $<0.001$ \\
\hline Mo & $1.05 \mathrm{~b}$ & $3.00 \mathrm{~b}$ & $1.42 \mathrm{~b}$ & $3.00 \mathrm{~b}$ & 2.3 & $<0.001$ \\
\hline $\mathrm{Na}$ & $262 \mathrm{~b}$ & $177 \mathrm{~b}$ & $457 \mathrm{ab}$ & $143 \mathrm{~b}$ & 688 & $<0.001$ \\
\hline $\mathrm{Ni}$ & $15.0 \mathrm{a}$ & $22.1 \mathrm{a}$ & $25.1 \mathrm{ab}$ & $29.3 \mathrm{a}$ & 9.3 & 0.001 \\
\hline $\mathrm{Pb}$ & $24.9 \mathrm{~b}$ & $600 \mathrm{a}$ & $682 \mathrm{a}$ & $954 \mathrm{a}$ & 186 & $<0.001$ \\
\hline $\mathrm{Se}$ & $2.00 \mathrm{a}$ & $2.30 \mathrm{a}$ & $2.00 \mathrm{a}$ & ND & 3.0 & 0.767 \\
\hline $\mathrm{Si}$ & ND & ND & ND & ND & ND & $<0.001$ \\
\hline $\mathrm{Sr}$ & ND & ND & ND & $19.1 \mathrm{~b}$ & ND & $<0.001$ \\
\hline $\mathrm{Ti}$ & $921 \mathrm{a}$ & $614 \mathrm{~b}$ & $632 \mathrm{a}$ & $533 \mathrm{a}$ & 461 & 0.146 \\
\hline V & $35.9 \mathrm{a}$ & $48.6 \mathrm{a}$ & $50.2 \mathrm{a}$ & $53.9 \mathrm{a}$ & 16 & $<0.001$ \\
\hline $\mathrm{Zn}$ & $85.0 \mathrm{~b}$ & $2101 \mathrm{~b}$ & $3688 \mathrm{a}$ & $4367 \mathrm{a}$ & 1193 & $<0.001$ \\
\hline
\end{tabular}

${ }^{\mathrm{e}}$ A: $100 \%$ soil, B: Mixture of $50 \%$ soil and $50 \%$ mine tailing, C: Mixture of 30\% soil and 70\% mine tailing, D: $100 \%$ mine tailing, ${ }^{\mathrm{f}}$ MSD: Minimum significant difference at $5 \%$ (SAS Institute 1989), ${ }^{\mathrm{g}}$ Mean of 27 plants $(n=27)$, i.e. three sampling points, i.e. 3,6 and 9 months, three plots and three plants per plot, ${ }^{\mathrm{h}}$ Values with the same letter are not significantly different between the mixtures (i.e. within the columns), ${ }^{\mathrm{i}}$ mean of 6 surviving plants, ${ }^{j} \mathrm{ND}$ : Not detected.

the uncultivated and non-rhizosphere and generally higher than in the roots and aboveground parts of $R$. communis (Suplementary Table 1). The concentrations of $\mathrm{As}, \mathrm{Cd}, \mathrm{Co}, \mathrm{Cr}, \mathrm{Cu}$, and $\mathrm{Pb}$ were lower in the aboveground parts of $R$. communis than in its roots when cultivated in a mixture of $50 \%$ mine tailings and $50 \%$ soil. The aboveground parts of $R$. communis accumulated $\mathrm{B}$ and Mo, while the roots accumulated Be and $\mathrm{Sr}(p<0.05)$ (Suplementary Table 1). The metal concentrations in the aboveground plant parts and roots of $R$. communis cultivated in the mixture of $50 \%$ soil and $50 \%$ mine tailings were also clearly different from those in the bulk, rhizospheric, and uncultivated mixture of $50 \%$ soil and $50 \%$ mine tailings (Fig. 3, Suplementary Table 1).

\section{Metal Concentrations when $R$. Communis was Cultivated in 30\% Soil and $70 \%$ Mine Tailings}

The concentrations of $\mathrm{As}, \mathrm{Cd}, \mathrm{Co}, \mathrm{Cr}, \mathrm{Cu}$, and $\mathrm{Pb}$ were lower in the rhizosphere than in the uncultivated and non-rhizosphere and generally higher than in 
Supplementary Table 1. Continued.

\begin{tabular}{|c|c|c|c|c|c|c|}
\hline \multicolumn{7}{|c|}{ C. Rhizosphere } \\
\hline Metal & $\mathrm{A}^{\mathrm{e}}$ & B & $\mathrm{C}$ & $\mathrm{D}$ & \multirow{2}{*}{$\mathrm{MSD}^{\mathrm{f}}$} & \multirow{2}{*}{$P$ value } \\
\hline & \multicolumn{4}{|c|}{$\mathrm{mg} \mathrm{Kg}^{-1}$ soil } & & \\
\hline $\mathrm{Ag}$ & $2.04^{\mathrm{g}} \mathrm{a}^{\mathrm{h}}$ & $1.03 \mathrm{a}$ & $1.31 \mathrm{~b}$ & $0.81^{\mathrm{i}} \mathrm{a}$ & 3.08 & 0.616 \\
\hline $\mathrm{Al}$ & $\mathrm{ND}^{\mathrm{j}}$ & $20.0 \mathrm{c}$ & $2.00 \mathrm{a}$ & $5654 \mathrm{a}$ & 1965 & $<0.001$ \\
\hline As & $662 \mathrm{a}$ & $795 \mathrm{~b}$ & $662 \mathrm{~b}$ & $2527 \mathrm{~b}$ & 1132 & 0.014 \\
\hline B & $0.87 \mathrm{~b}$ & $0.96 \mathrm{~b}$ & ND & ND & 2.17 & 0.345 \\
\hline $\mathrm{Ba}$ & $151 \mathrm{~b}$ & $128 \mathrm{a}$ & $94.2 \mathrm{a}$ & $710 \mathrm{a}$ & 89.4 & 0.107 \\
\hline $\mathrm{Be}$ & $0.10 \mathrm{a}$ & $0.10 \mathrm{~b}$ & $0.09 \mathrm{~b}$ & ND & 0.31 & 0.854 \\
\hline $\mathrm{Ca}\left(\mathrm{x} 10^{3}\right)$ & $25 \mathrm{a}$ & $42 \mathrm{~b}$ & $40 \mathrm{~b}$ & $49 \mathrm{a}$ & 21 & 0.053 \\
\hline $\mathrm{Cd}$ & $24.0 \mathrm{a}$ & $59.1 \mathrm{~b}$ & $86 \mathrm{a}$ & $59.0 \mathrm{~b}$ & 40 & 0.022 \\
\hline Co & $11.2 \mathrm{a}$ & $15.7 \mathrm{a}$ & $14.4 \mathrm{a}$ & $17.1 \mathrm{~b}$ & 4.7 & 0.054 \\
\hline $\mathrm{Cr}$ & $29.5 \mathrm{a}$ & $28.6 \mathrm{a}$ & $17.4 \mathrm{a}$ & $19.2 \mathrm{a}$ & 15 & 0.012 \\
\hline $\mathrm{Cu}$ & $253 \mathrm{a}$ & $543 \mathrm{~b}$ & $570 \mathrm{~b}$ & $836 \mathrm{~b}$ & 379 & 0.033 \\
\hline $\mathrm{Fe}\left(\mathrm{x} 10^{3}\right)$ & $27 \mathrm{a}$ & $44 \mathrm{~b}$ & $40 \mathrm{~b}$ & $50 \mathrm{~b}$ & 18 & 0.034 \\
\hline $\mathrm{K}$ & ND & $1768 \mathrm{a}$ & ND & $2815 \mathrm{a}$ & 1878 & 0.025 \\
\hline $\mathrm{Li}$ & ND & $14.0 \mathrm{a}$ & ND & $15.1 \mathrm{a}$ & 14 & 0.058 \\
\hline $\mathrm{Mg}$ & $6515 \mathrm{a}$ & $5404 \mathrm{a}$ & $4523 \mathrm{a}$ & $3147 \mathrm{a}$ & 1582 & 0.024 \\
\hline $\mathrm{Mn}$ & $443 \mathrm{a}$ & $629 \mathrm{~b}$ & $605 \mathrm{~b}$ & $772 \mathrm{a}$ & 265 & 0.069 \\
\hline Mo & $1.00 \mathrm{~b}$ & $1.96 \mathrm{bc}$ & $2.00 \mathrm{~b}$ & $4.05 \mathrm{ab}$ & 2.2 & 0.012 \\
\hline $\mathrm{Na}$ & ND & $513 \mathrm{ab}$ & ND & $980 \mathrm{a}$ & 540 & 0.024 \\
\hline $\mathrm{Ni}$ & $18.2 \mathrm{a}$ & $26.2 \mathrm{a}$ & $17.5 \mathrm{ab}$ & $23.3 \mathrm{a}$ & 12 & 0.05 \\
\hline $\mathrm{Pb}$ & $201 \mathrm{a}$ & $501 \mathrm{~b}$ & $459 \mathrm{~b}$ & $679 \mathrm{~b}$ & 290 & 0.01 \\
\hline $\mathrm{Se}$ & $5.96 \mathrm{a}$ & $7.00 \mathrm{a}$ & $3.02 \mathrm{a}$ & ND & 13 & 0.742 \\
\hline $\mathrm{Si}$ & $4.00 \mathrm{~b}$ & $262 \mathrm{a}$ & $12.05 b$ & $517 \mathrm{a}$ & 399 & 0.009 \\
\hline $\mathrm{Sr}$ & ND & ND & $15.7 \mathrm{a}$ & $91.6 \mathrm{a}$ & 187 & 0.288 \\
\hline $\mathrm{Ti}$ & $864 \mathrm{a}$ & $760 \mathrm{ab}$ & $646 \mathrm{a}$ & $662 \mathrm{a}$ & 428 & 0.378 \\
\hline $\mathrm{V}$ & $38.6 \mathrm{a}$ & $41.5 \mathrm{a}$ & $39.4 \mathrm{~b}$ & $47.2 \mathrm{a}$ & 17 & 0.869 \\
\hline $\mathrm{Zn}$ & $1079 \mathrm{a}$ & $1953 \mathrm{~b}$ & $1790 \mathrm{~b}$ & $3391 \mathrm{a}$ & 1565 & 0.147 \\
\hline
\end{tabular}

${ }^{\mathrm{e}} \mathrm{A}$ : $100 \%$ soil, B: Mixture of $50 \%$ soil and $50 \%$ mine tailing, C: Mixture of 30\% soil and 70\% mine tailing, D: $100 \%$ mine tailing, ${ }^{\mathrm{f}}$ MSD: Minimum significant difference at $5 \%$ (SAS Institute 1989), ${ }^{\mathrm{g}}$ Mean of 27 plants $(n=27)$, i.e. three sampling points, i.e. 3 , 6 and 9 months, three plots and three plants per plot, ${ }^{\mathrm{h}}$ Values with the same letter are not significantly different between the mixtures (i.e. within the columns), ${ }^{i}$ mean of 6 surviving plants, ${ }^{j}$ ND: Not detected.

the roots and aboveground parts of $R$. communis (Suplemmentary Table 1). The concentrations of As, $\mathrm{Cd}, \mathrm{Co}, \mathrm{Cr}, \mathrm{Cu}$, and $\mathrm{Pb}$ were lower in the aboveground parts of $R$. communis than in its roots when cultivated in a mixture of $30 \%$ mine tailings and $70 \%$ soil. The metal concentrations in the aboveground plant parts and roots of $R$. communis cultivated in the mixture of $30 \%$ soil and $70 \%$ mine tailings were different from those in the non-rhizosphere, rhizosphere, and uncultivated mixture of $30 \%$ soil and $70 \%$ mine tailings (Fig. 4, Suplementary Table 1).

\section{Metal Concentrations when $R$. Communis was Cultivated in $100 \%$ Mine Tailings}

The concentrations of $\mathrm{As}, \mathrm{Cd}, \mathrm{Co}, \mathrm{Cu}$, and $\mathrm{Pb}$ were lower in the rhizosphere than in the uncultivated and non-rhizosphere, and generally higher than in the roots and aboveground parts of $R$. communis (Suplementary Table 1). The concentrations of $\mathrm{As}, \mathrm{Cd}, \mathrm{Co}, \mathrm{Cr}, \mathrm{Cu}$, and $\mathrm{Pb}$ were lower in the aboveground parts of $R$. communis than in its roots when cultivated in a mixture of $30 \%$ 
Supplementary Table 1. Continued.

\begin{tabular}{|c|c|c|c|c|c|c|}
\hline \multicolumn{7}{|c|}{ D. Plant } \\
\hline \multirow{2}{*}{ Metal } & $\mathrm{A}^{\mathrm{e}}$ & B & $\mathrm{C}$ & $\mathrm{D}$ & \multirow{2}{*}{$\mathrm{MSD}^{\mathrm{f}}$} & \multirow{2}{*}{$P$ value } \\
\hline & \multicolumn{4}{|c|}{$\mathrm{mg} \mathrm{Kg}^{-1}$ soil } & & \\
\hline $\mathrm{Ag}$ & $0.30^{\mathrm{g}} \mathrm{a}^{\mathrm{h}}$ & $0.40 \mathrm{a}$ & $0.40 \mathrm{~b}$ & $0.96^{\mathrm{i}} \mathrm{a}$ & 0.9 & $<0.001$ \\
\hline $\mathrm{Al}$ & 469 a & $574 \mathrm{~b}$ & $1252 \mathrm{a}$ & $758 \mathrm{a}$ & 1697 & 0.191 \\
\hline As & $23.0 \mathrm{~b}$ & $6.20 \mathrm{~d}$ & $155 \mathrm{~b}$ & $458 \mathrm{c}$ & 485 & 0.179 \\
\hline B & $312 \mathrm{a}$ & $327 \mathrm{a}$ & $277 \mathrm{a}$ & $47.2 \mathrm{a}$ & 299 & 0.538 \\
\hline $\mathrm{Ba}$ & $19.0 \mathrm{c}$ & $97.0 \mathrm{a}$ & $97.1 \mathrm{a}$ & $17.0 \mathrm{a}$ & 363 & 0.719 \\
\hline $\mathrm{Be}$ & $0.10 \mathrm{a}$ & $0.10 \mathrm{~b}$ & $0.64 \mathrm{~b}$ & $3.70 \mathrm{a}$ & 0.90 & $<0.001$ \\
\hline $\mathrm{Ca}\left(\mathrm{x} 10^{3}\right)$ & $8 \mathrm{~b}$ & $10 \mathrm{c}$ & $13 \mathrm{c}$ & $18 \mathrm{~b}$ & 8 & 0.011 \\
\hline $\mathrm{Cd}$ & $1.00 \mathrm{~b}$ & $1.00 \mathrm{~d}$ & $6.10 \mathrm{~b}$ & $13.0 \mathrm{c}$ & 16 & 0.164 \\
\hline $\mathrm{Co}$ & $1.00 \mathrm{c}$ & $1.00 \mathrm{~b}$ & $2.10 \mathrm{~b}$ & $8.20 \mathrm{c}$ & 4.0 & 0.004 \\
\hline $\mathrm{Cr}$ & $5.00 \mathrm{~b}$ & $7.02 \mathrm{~b}$ & $7.10 \mathrm{~b}$ & $16.4 \mathrm{ab}$ & 8.0 & 0.174 \\
\hline $\mathrm{Cu}$ & $13.8 \mathrm{~b}$ & $12.1 \mathrm{c}$ & $61.0 \mathrm{c}$ & $129 \mathrm{c}$ & 192 & 0.255 \\
\hline $\mathrm{Fe}\left(\mathrm{x} 10^{3}\right)$ & $1 \mathrm{c}$ & $1 \mathrm{~d}$ & $3 \mathrm{c}$ & $11 \mathrm{c}$ & 8 & 0.036 \\
\hline K & $136 \mathrm{~b}$ & $\mathrm{ND}^{\mathrm{j}}$ & $80.0 \mathrm{~b}$ & ND & 577 & 0.756 \\
\hline $\mathrm{Li}$ & $4.05 \mathrm{a}$ & $5.99 \mathrm{ab}$ & $5.90 \mathrm{a}$ & $4.00 \mathrm{a}$ & 6.78 & 0.826 \\
\hline $\mathrm{Mg}$ & $2761 \mathrm{~b}$ & $2685 \mathrm{c}$ & $3262 \mathrm{~b}$ & $3218 \mathrm{a}$ & 1426 & 0.408 \\
\hline $\mathrm{Mn}$ & $37.0 \mathrm{c}$ & $24.6 \mathrm{~d}$ & $65.0 \mathrm{c}$ & $230 \mathrm{~b}$ & 128 & 0.022 \\
\hline Mo & $3.89 \mathrm{a}$ & $5.00 \mathrm{a}$ & $4.60 \mathrm{a}$ & $7.80 \mathrm{a}$ & 3.0 & 0.16 \\
\hline $\mathrm{Na}$ & $656 \mathrm{ab}$ & $946 \mathrm{a}$ & $820 \mathrm{a}$ & ND & 1382 & 0.6786 \\
\hline $\mathrm{Ni}$ & $5.80 \mathrm{~b}$ & $6.04 \mathrm{~b}$ & $9.00 \mathrm{~b}$ & $10.89 \mathrm{~b}$ & 7.4 & 0.306 \\
\hline $\mathrm{Pb}$ & $9.01 \mathrm{~b}$ & $5.10 \mathrm{~d}$ & $47.2 \mathrm{c}$ & $93.0 \mathrm{c}$ & 124 & 0.23 \\
\hline $\mathrm{Se}$ & $3.04 \mathrm{a}$ & $3.20 \mathrm{ab}$ & $4.42 \mathrm{a}$ & $13.3 \mathrm{a}$ & 4.0 & 0.022 \\
\hline $\mathrm{Si}$ & $451 \mathrm{a}$ & $450 \mathrm{a}$ & $404 \mathrm{a}$ & $14.0 \mathrm{~b}$ & 444 & 0.682 \\
\hline $\mathrm{Sr}$ & $7.98 \mathrm{a}$ & $4.03 \mathrm{a}$ & $1.93 \mathrm{a}$ & $28.1 \mathrm{~b}$ & 18 & 0.125 \\
\hline $\mathrm{Ti}$ & $23.0 \mathrm{c}$ & $23.2 \mathrm{~d}$ & $54.6 \mathrm{~b}$ & $23.2 \mathrm{~b}$ & 96 & 0.401 \\
\hline $\mathrm{V}$ & $0.10 \mathrm{~b}$ & ND & $2.40 \mathrm{c}$ & $8.90 \mathrm{~b}$ & 7.80 & 0.069 \\
\hline $\mathrm{Zn}$ & $80.0 \mathrm{~b}$ & $71.0 \mathrm{c}$ & $260 \mathrm{c}$ & $867 \mathrm{~b}$ & 562 & 0.027 \\
\hline
\end{tabular}

${ }^{\mathrm{e}} \mathrm{A}: 100 \%$ soil, B: Mixture of $50 \%$ soil and $50 \%$ mine tailing, C: Mixture of 30\% soil and 70\% mine tailing, D: $100 \%$ mine tailing, ${ }^{\mathrm{f}}$ MSD: Mimimum significant difference at $5 \%$ (SAS Institute 1989), ${ }^{\mathrm{g}}$ Mean of 27 plants $(n=27)$, i.e. three sampling points, i.e. 3 , 6 and 9 months, three plots and three plants per plot, ${ }^{\mathrm{h}}$ Values with the same letter are not significantly different between the mixtures (i.e. within the columns), ${ }^{\mathrm{i}}$ mean of 6 surviving plants, ${ }^{\mathrm{j}} \mathrm{ND}$ : Not detected.

mine tailings and $70 \%$ soil. The metal concentrations in the roots and aboveground parts of plants cultivated in $100 \%$ mine tailings were clearly different from the concentration of the metals in the rhizosphere and the mine tailings cultivated or uncultivated (Fig. 5, Suplementary Table 1).

Apart from $\mathrm{Be}, \mathrm{Mo}, \mathrm{Se}$, and $\mathrm{Si}$, none of the concentrations of the metals monitored was higher in the aboveground plant parts than in the non-rhizosphere, mine tailings, and their mixtures (Suplementary Table 1). The ratio of the heavy metals $\mathrm{As}, \mathrm{Cd}, \mathrm{Cu}$, and
$\mathrm{Pb}$ in the aboveground plant parts of $R$. communis to the concentration in the non-rhizosphere soil increased with increased amount of mine tailings in the mixture, but remained $<0.12$. For instance, the ratio of $\mathrm{Cd}$ increased from 0.01 in the mixture $50 \%$ soil and $50 \%$ mine tailings to 0.06 in the $30 \%$ and $70 \%$ mixture and increased to 0.10 in the $100 \%$ mine tailings. The ratio of the heavy metals $\mathrm{As}, \mathrm{Cd}, \mathrm{Cu}$, and $\mathrm{Pb}$ in the rhizosphere of $R$. communis to the concentration in the non-rhizosphere fluctuated between 0.6 and 0.8 . 
Supplementary Table 1 . Continued.

\begin{tabular}{|c|c|c|c|c|c|c|}
\hline \multicolumn{7}{|c|}{ E. Root } \\
\hline \multirow{2}{*}{ Metal } & $\mathrm{A}^{\mathrm{e}}$ & $\mathrm{B}$ & $\mathrm{C}$ & $\mathrm{D}$ & \multirow{2}{*}{$\mathrm{MSD}^{\mathrm{f}}$} & \multirow{2}{*}{$P$ value } \\
\hline & \multicolumn{4}{|c|}{$\mathrm{mg} \mathrm{Kg}^{-1}$ soil } & & \\
\hline $\mathrm{Ag}$ & $1.37^{\mathrm{g}} \mathrm{a}^{\mathrm{h}}$ & $1.30 \mathrm{a}$ & $1.31 \mathrm{~b}$ & $\mathrm{ND}^{\mathrm{j}}$ & 2.03 & 0.574 \\
\hline $\mathrm{Al}$ & $781 \mathrm{a}$ & $966 \mathrm{a}$ & $1188 \mathrm{a}$ & $3051^{\mathrm{i}} \mathrm{a}$ & 1512 & 0.152 \\
\hline As & $55 \mathrm{~b}$ & $366 \mathrm{c}$ & $504 \mathrm{~b}$ & $146 \mathrm{c}$ & 682 & 0.18 \\
\hline B & $50.6 \mathrm{~b}$ & $40.8 \mathrm{~b}$ & $53.6 \mathrm{~b}$ & $30.3 \mathrm{a}$ & 55.4 & 0.83 \\
\hline $\mathrm{Ba}$ & $58.0 \mathrm{c}$ & $40.0 \mathrm{a}$ & $22.1 \mathrm{a}$ & $18.0 \mathrm{a}$ & 72.2 & 0.516 \\
\hline $\mathrm{Be}$ & $0.50 \mathrm{a}$ & $0.20 \mathrm{~b}$ & $0.09 \mathrm{~b}$ & $2.30 \mathrm{~b}$ & 1.21 & 0.102 \\
\hline $\mathrm{Ca}\left(\mathrm{x} 10^{3}\right)$ & $8 \mathrm{~b}$ & $12 \mathrm{c}$ & $12 \mathrm{c}$ & $7 \mathrm{~b}$ & 15 & 0.733 \\
\hline $\mathrm{Cd}$ & $2.00 \mathrm{~b}$ & $13.0 \mathrm{c}$ & $19.3 \mathrm{~b}$ & $17.0 \mathrm{c}$ & 22 & 0.08 \\
\hline Co & $8.00 \mathrm{~b}$ & $3.30 \mathrm{~b}$ & $3.50 \mathrm{~b}$ & $8.0 \mathrm{c}$ & 6 & 0.413 \\
\hline $\mathrm{Cr}$ & $10.5 \mathrm{~b}$ & $10.6 \mathrm{~b}$ & $5.60 \mathrm{~b}$ & $4.70 \mathrm{~b}$ & 12 & 0.54 \\
\hline $\mathrm{Cu}$ & $28.5 \mathrm{~b}$ & $106 \mathrm{c}$ & $163 \mathrm{c}$ & $157 \mathrm{c}$ & 278 & 0.159 \\
\hline $\mathrm{Fe}\left(\mathrm{x} 10^{3}\right)$ & $6 \mathrm{c}$ & $11 \mathrm{c}$ & $13 \mathrm{c}$ & $6 \mathrm{c}$ & 16 & 0.572 \\
\hline K & $2.30 \mathrm{~b}$ & $13.1 \mathrm{~b}$ & $11.0 \mathrm{~b}$ & $34.4 \mathrm{~b}$ & 24 & 0.188 \\
\hline $\mathrm{Li}$ & $6.06 \mathrm{a}$ & $1.0 \mathrm{~b}$ & $2.48 \mathrm{a}$ & ND & 4 & 0.524 \\
\hline $\mathrm{Mg}$ & $3541 \mathrm{~b}$ & $3527 \mathrm{~b}$ & $3210 \mathrm{~b}$ & $3173 \mathrm{a}$ & 2225 & 0.962 \\
\hline $\mathrm{Mn}$ & $95.0 \mathrm{c}$ & $113 \mathrm{c}$ & $137 \mathrm{c}$ & $190 \mathrm{~b}$ & 205 & 0.856 \\
\hline Mo & $1.39 \mathrm{~b}$ & $1.43 \mathrm{c}$ & $1.90 \mathrm{~b}$ & $4.10 \mathrm{ab}$ & 2 & 0.092 \\
\hline $\mathrm{Na}$ & $143 \mathrm{~b}$ & ND & ND & ND & 4 & 0.5737 \\
\hline $\mathrm{Ni}$ & $7.00 \mathrm{~b}$ & $9.20 \mathrm{~b}$ & $10.0 \mathrm{~b}$ & $12.3 \mathrm{~b}$ & 9.8 & 0.578 \\
\hline $\mathrm{Pb}$ & $28 \mathrm{~b}$ & $111 \mathrm{c}$ & $168 \mathrm{c}$ & $123 \mathrm{c}$ & 177 & 0.093 \\
\hline $\mathrm{Se}$ & $9.00 \mathrm{a}$ & $2.30 \mathrm{ab}$ & $4.29 \mathrm{a}$ & $6.00 \mathrm{~b}$ & 14 & 0.725 \\
\hline $\mathrm{Si}$ & $288 \mathrm{a}$ & $411 \mathrm{a}$ & $434 \mathrm{a}$ & $407 \mathrm{ab}$ & 382 & 0.669 \\
\hline $\mathrm{Sr}$ & $12.7 \mathrm{a}$ & $20.4 \mathrm{a}$ & $22.4 \mathrm{a}$ & $32.7 \mathrm{~b}$ & 24 & 0.489 \\
\hline $\mathrm{Ti}$ & $280 \mathrm{~b}$ & $208 \mathrm{c}$ & $142 \mathrm{~b}$ & $99.0 \mathrm{~b}$ & 357 & 0.716 \\
\hline V & $8.30 \mathrm{~b}$ & $3.50 \mathrm{~b}$ & $3.06 \mathrm{c}$ & ND & 11 & 0.5 \\
\hline $\mathrm{Zn}$ & $92.0 \mathrm{~b}$ & $168 \mathrm{c}$ & $389 \mathrm{c}$ & $296 \mathrm{~b}$ & 387 & 0.046 \\
\hline
\end{tabular}

${ }^{\mathrm{e}} \mathrm{A}$ : $100 \%$ soil, B: Mixture of $50 \%$ soil and $50 \%$ mine tailing, C: Mixture of 30\% soil and 70\% mine tailing, D: $100 \%$ mine tailing, ${ }_{\mathrm{f}}^{\mathrm{f}}$ MSD: Mimimum significant difference at $5 \%$ (SAS Institute 1989), ${ }^{\mathrm{g}}$ Mean of 27 plants $(n=27)$, i.e. three sampling points, i.e. 3 , 6 and 9 months, three plots and three plants per plot, ${ }^{\mathrm{h}}$ Values with the same letter are not significantly different between the mixtures (i.e. within the columns), ${ }^{i}$ mean of 6 surviving plants, ${ }^{j}$ ND: Not detected.

Metals in the Uncultivated, Rhizosphere, and Non-Rhizosphere Soil-Mine Tailing Mixtures, and in the Roots and Aboveground Parts of $R$. communis

The PCA to metals in the uncultivated soil-mine tailing mixtures, separated clearly uncultivated soil from the mixtures of soil and mine tailings, and the mine tailings (Fig. 6). The uncultivated soil had a negative $\mathrm{PCl}$ (loaded by $\mathrm{Ba}, \mathrm{Mg}$, and $\mathrm{Ti}$ ) while the mixtures of soil and mine tailings and the mine tailings were characterized by a positive PC1 (loaded by $\mathrm{Al}, \mathrm{As}, \mathrm{Ca}, \mathrm{Cd}, \mathrm{Co} \mathrm{Cu}, \mathrm{Fe}, \mathrm{Li}, \mathrm{Mn}, \mathrm{Mo}, \mathrm{Ni}, \mathrm{Pb}, \mathrm{V}$, $\mathrm{Zn})$. The mixtures of soil and mine tailings were separated and the mixture of $30 \%$ soil and $70 \%$ mine tailings was characterized mostly by a negative PC2 and the mixture of $50 \%$ soil and $50 \%$ mine tailings.

The PCA to the metals in the non-rhizosphere soilmine tailing mixtures separated clearly the soil, mine tailings, and their mixtures (Fig. 7). The concentrations of $\mathrm{Ag}, \mathrm{As}, \mathrm{Ca}, \mathrm{Cd}, \mathrm{Co}, \mathrm{Cr}, \mathrm{Cu} \mathrm{Fe}, \mathrm{Mn}, \mathrm{Mo}, \mathrm{Ni}, \mathrm{Pb}, \mathrm{V}$, 


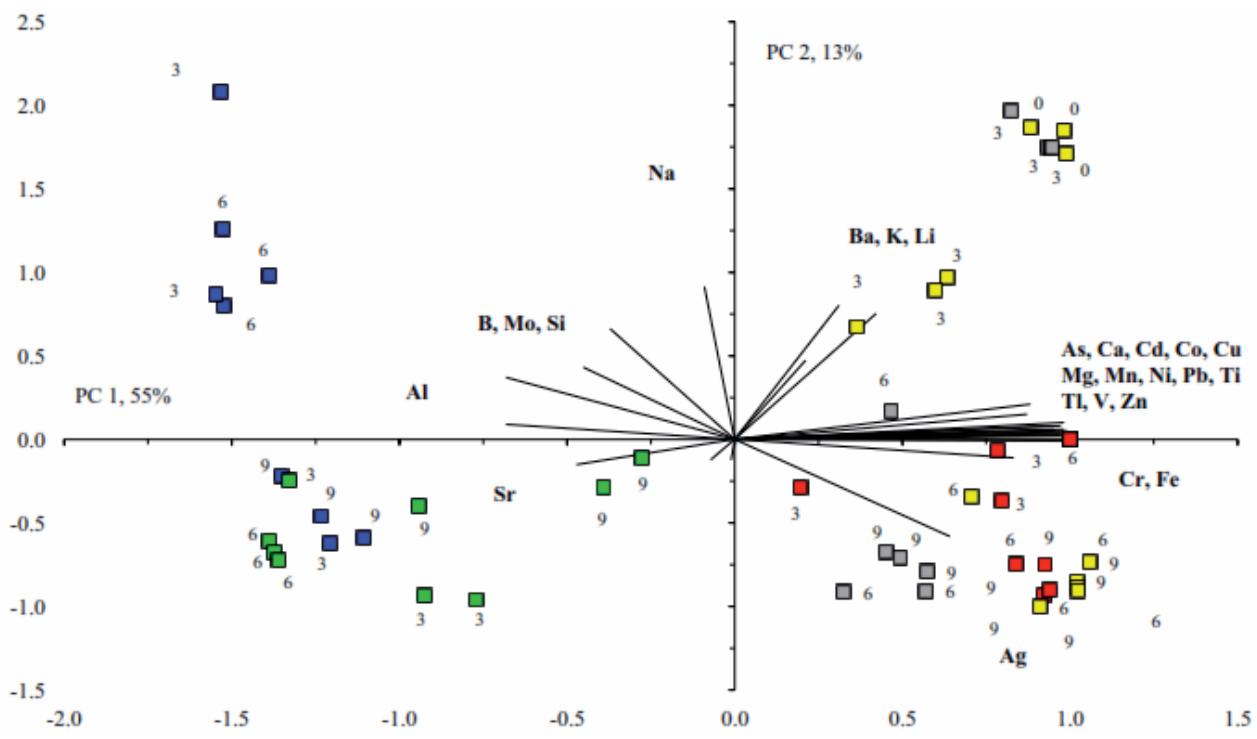

Fig. 3. Principal component analysis with the concentration of the different elements measured in the roots ( $\square$ ) and aboveground parts of Ricinus communis L. (অ), and in the uncultivated mixture of soil (at 50\%) and mine tailings (at 50\%) ( $\square$ ), the non-rhizosphere mixture $(\square)$, and the rhizosphere ( $\square$ ). Samples were taken at the onset of the experiment (0) and after 3, 6, or 9 months. Principal component 1 (PC1) explained $55 \%$ of the variation and PC2 13\%.

and $\mathrm{Zn}$ was lowest in the $100 \%$ soil and increased with an increased percentage of mine tailings (Fig. 7). The soil was characterized by a larger concentration of $\mathrm{B}$, $\mathrm{Ba}, \mathrm{Mg}$, and $\mathrm{Ti}$ than the mine tailings and their mixtures.

The concentrations of $\mathrm{As}, \mathrm{Cd}, \mathrm{Co}, \mathrm{Cr}, \mathrm{Cu}$, and $\mathrm{Pb}$ in the rhizosphere of $R$. Communis cultivated in soil-mine tailing mixtures increased generally with the increased amount of mine tailings in the mixture, but the effect was less accentuated than in the non-rhizosphere soil (Suplementary Table 1). Additionally, the rhizosphere of $R$. communis cultivated in the mixtures of mine tailings and soil was not as clearly separated in the PCA as the non-rhizosphere (Figs 7-8). The concentrations of $\mathrm{Al}, \mathrm{As}, \mathrm{Ca}, \mathrm{Cd}, \mathrm{Co}, \mathrm{Cu}, \mathrm{Fe}, \mathrm{Mn}, \mathrm{Mo}, \mathrm{Pb}, \mathrm{Tl}, \mathrm{V}$, and $\mathrm{Zn}$ (loaded PC1) did not separate the rhizosphere of the different mixtures, but the concentrations of $\mathrm{Cr}$, K, $\mathrm{Li}, \mathrm{Na}, \mathrm{Ni}$, and $\mathrm{Si}$ did (loaded PC2). The soil and the mixture $50 \%$ soil and $50 \%$ mine tailings had generally a larger concentration of $\mathrm{Cr}, \mathrm{K}, \mathrm{Li}, \mathrm{Na}, \mathrm{Ni}$, and $\mathrm{Si}$ than the $30 \%$ soil $70 \%$ mine tailings, but not the $100 \%$ mine tailings.

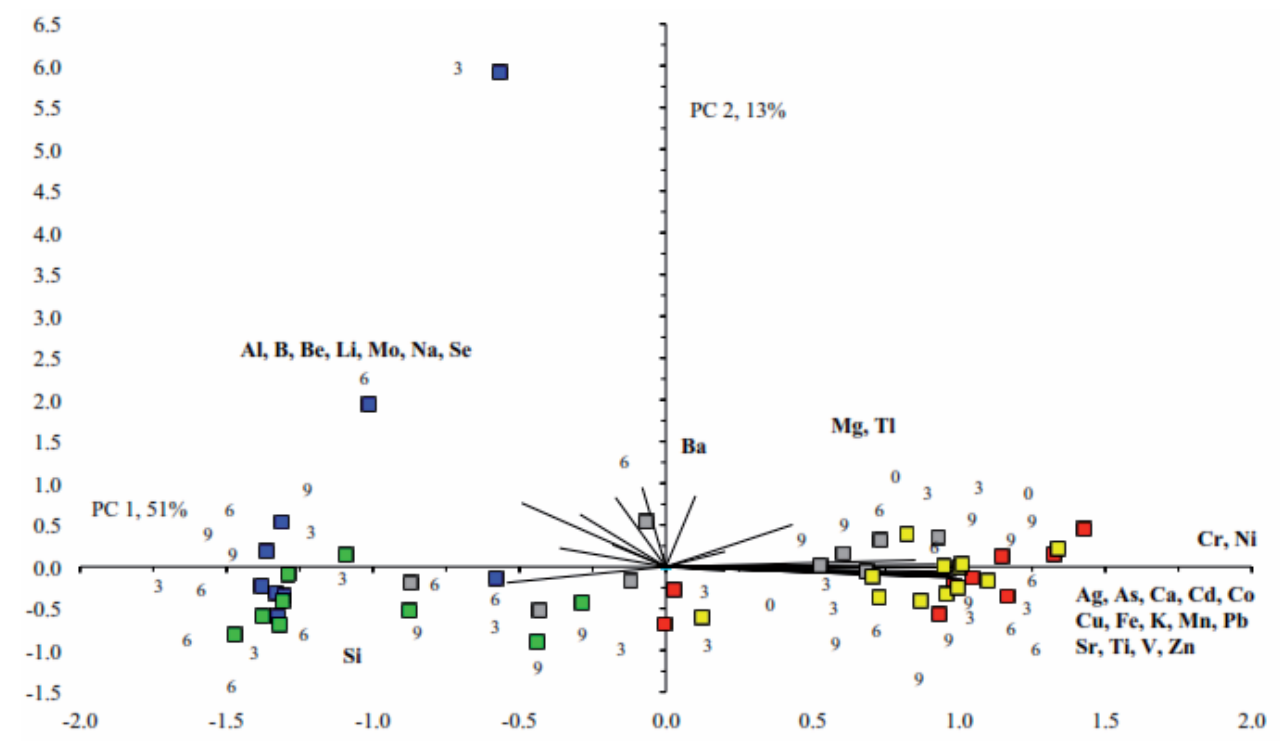

Fig. 4. Principal component analysis with the concentration of the different elements measured in the roots ( $\square$ ) and aboveground parts of

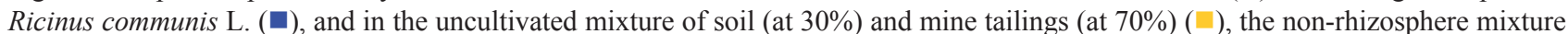
$(\square)$, and the rhizosphere ( $\square$ ). Samples were taken at the onset of the experiment (0) and after 3, 6, or 9 months. Principal component 1 (PC1) explained $51 \%$ of the variation and PC2 13\%. 


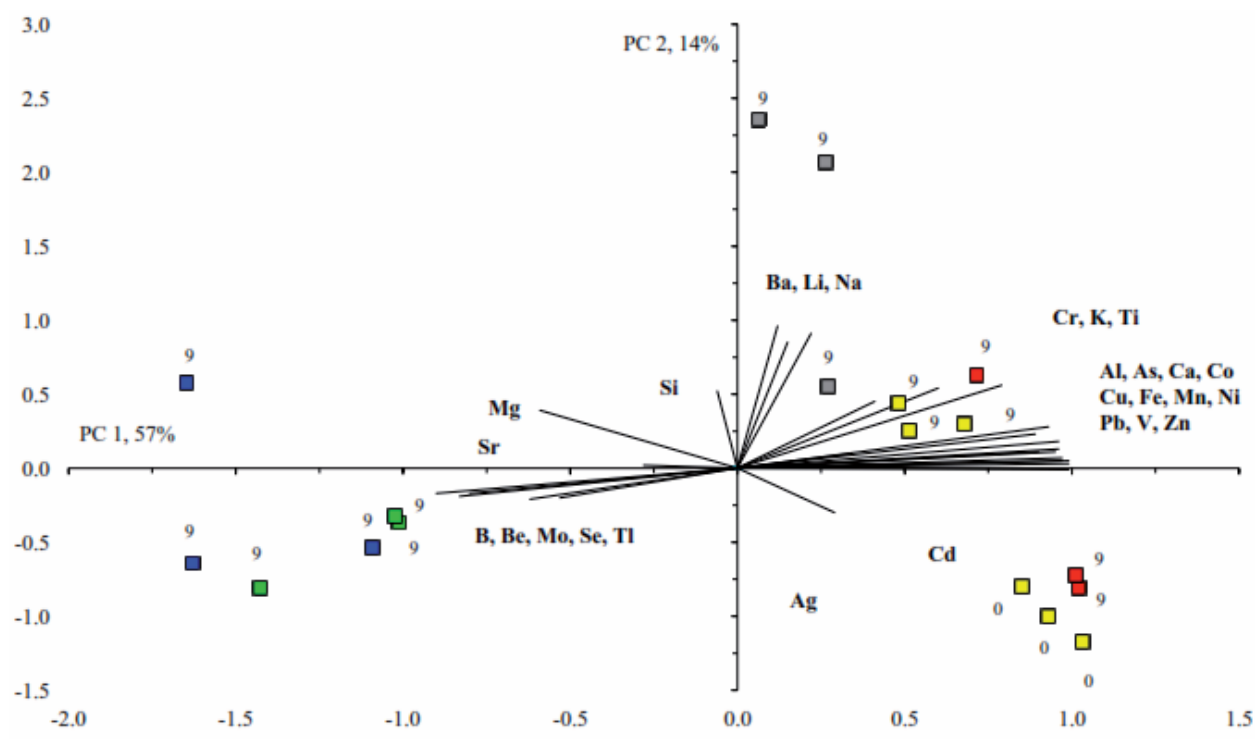

Fig. 5. Principal component analysis with the concentration of the different elements measured in the roots ( $\square)$ and aboveground parts of Ricinus communis L. ( $\square$ ), and in the uncultivated mine tailings ( $\square$ ), the non-rhizosphere mine tailings ( $\square$ ), and the rhizosphere ( $\square$ ). Samples were taken at the onset of the experiment (0) and after 3, 6, or 9 months. Principal component 1 (PC1) explained 57\% of the variation and PC2 14\%.

The concentration of metals in the roots of $R$. communis cultivated in soil-mine tailing mixtures was affected less by the mixture in which the plant grew, but more by the age of the roots (Fig. 9). The roots of 9-month old plants were characterized by a larger concentration of $\mathrm{As}, \mathrm{Ca}, \mathrm{Cd}, \mathrm{Co}, \mathrm{Cu}, \mathrm{Fe}, \mathrm{K}, \mathrm{Mn}, \mathrm{Ni}$, $\mathrm{Pb}, \mathrm{Si}$, and $\mathrm{Zn}$ than the amounts found in the roots of younger plants. The roots of 9-month old $R$. communis plants grown in the soil were characterized by a larger concentration of $\mathrm{Ag}, \mathrm{Ba}, \mathrm{Cr}, \mathrm{Mg}, \mathrm{Ti}$, and $\mathrm{V}$ than the younger other roots, i.e., a larger positive $\mathrm{PC} 2$.
For metals concentration in the aboveground parts of $R$. communis cultivated in soil-mine tailing mixtures, the PCA did not separate the aboveground parts of $R$. communis when the plant was cultivated in soil, the mixture of $30 \%$ or $50 \%$ soil with $70 \%$ or $50 \%$ mine tailings (Fig. 10). However, the metal concentrations in the aboveground material of R. communis when cultivated in $100 \%$ mine tailings was separated clearly and the amount of $\mathrm{Ag}, \mathrm{As}, \mathrm{Ca}$, $\mathrm{Cd}, \mathrm{Co}, \mathrm{Cr}, \mathrm{Cu}, \mathrm{Fe}, \mathrm{Mn}, \mathrm{Mo}, \mathrm{Pb}, \mathrm{V}$, and $\mathrm{Zn}$ was higher than when plants were cultivated in the soil,

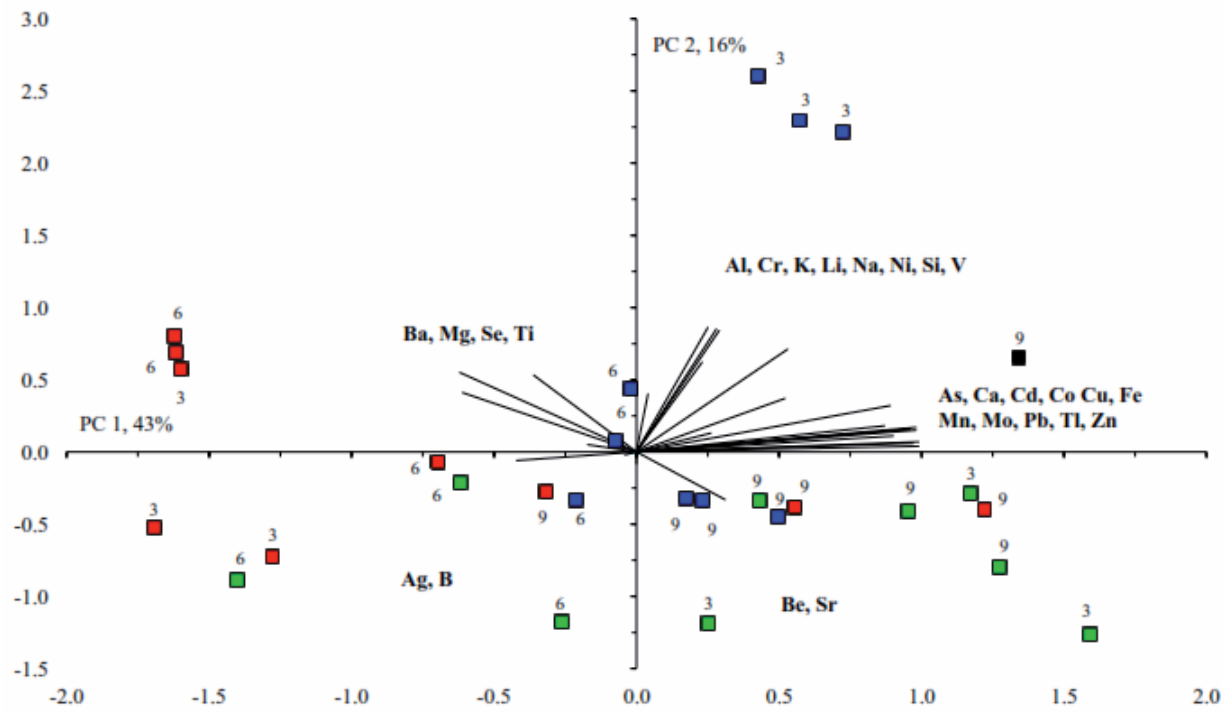

Fig. 6. Principal component analysis with the concentrations of the different elements in the rhizosphere of Ricinus communis L. cultivated in soil ( $\square$ ), in a mixture of $50 \%$ soil and $50 \%$ mine tailings $(\square)$, in a mixture of $30 \%$ soil and $70 \%$ mine tailings $(\square)$, and mine tailings $(100 \%)(\square)$. Samples were taken at the onset of the experiment $(0)$ and after 3, 6, or 9 months. Principal component 1 (PC1) explained $43 \%$ of the variation and PC2 $16 \%$. 


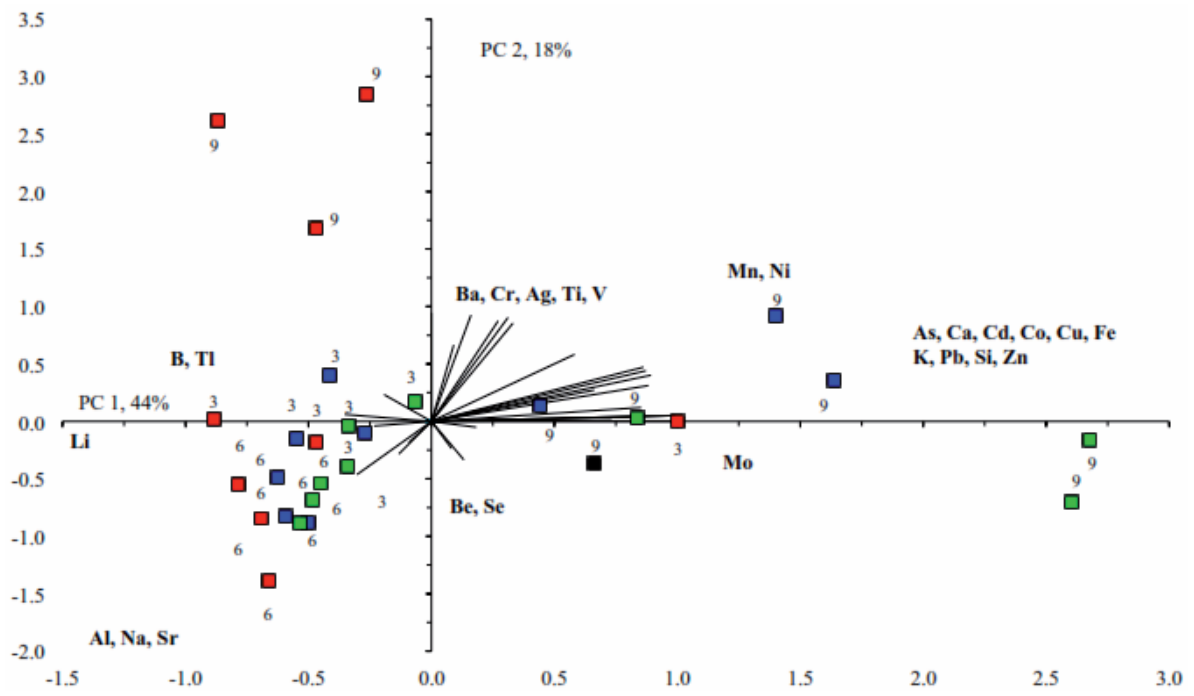

Fig. 7. Principal component analysis with the concentrations of the different elements in the roots of Ricinus communis L. cultivated

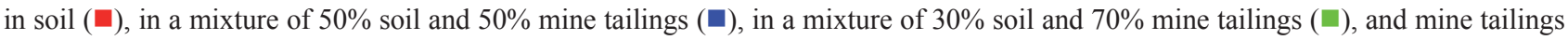
$(100 \%)(\square)$. Samples were taken at the onset of the experiment (0) and after 3, 6, or 9 months. Principal component 1 (PC1) explained $44 \%$ of the variation and $\mathrm{PC} 218 \%$.

the mixture of $30 \%$ or $50 \%$ soil with $70 \%$ or $50 \%$ mine tailings.

\section{Discussion}

The organic carbon content in all treatments was higher at the end of the experiment ( $>1.2$ times) than at the beginning. Wu et al. [23] found that bulk density and soil nutrients increased in waste land soil when cultivated with $R$. communis for 2 years.
Concentrations of some heavy metals found in this study were higher than values reported for other mine wastes in Mexico and high compared to those reported for normal soil. For instance, the concentration of $17 \mathrm{mg} \mathrm{Co} \mathrm{kg}{ }^{-1}$ was much higher than that reported for a normal soil $\left(0.1 \mathrm{mg}\right.$ Co $\left.\mathrm{kg}^{-1}\right)$ or that $\left(4 \mathrm{mg} \mathrm{Co} \mathrm{kg}^{-1}\right)$ found in a mine tailing in San Luis Potosi (Mexico), active since 1800 [24]. The concentrations of $120 \mathrm{mg} \mathrm{Cd} \mathrm{kg}^{-1}$ and $910 \mathrm{mg} \mathrm{Pb} \mathrm{kg}^{-1}$ were higher than those reported for mine tailings in San Luis Potosi (81 $\mathrm{mg} \mathrm{Cd} \mathrm{kg}^{-1}$ and $754 \mathrm{mg} \mathrm{Pb} \mathrm{kg}{ }^{-1}$ ) [24] and much

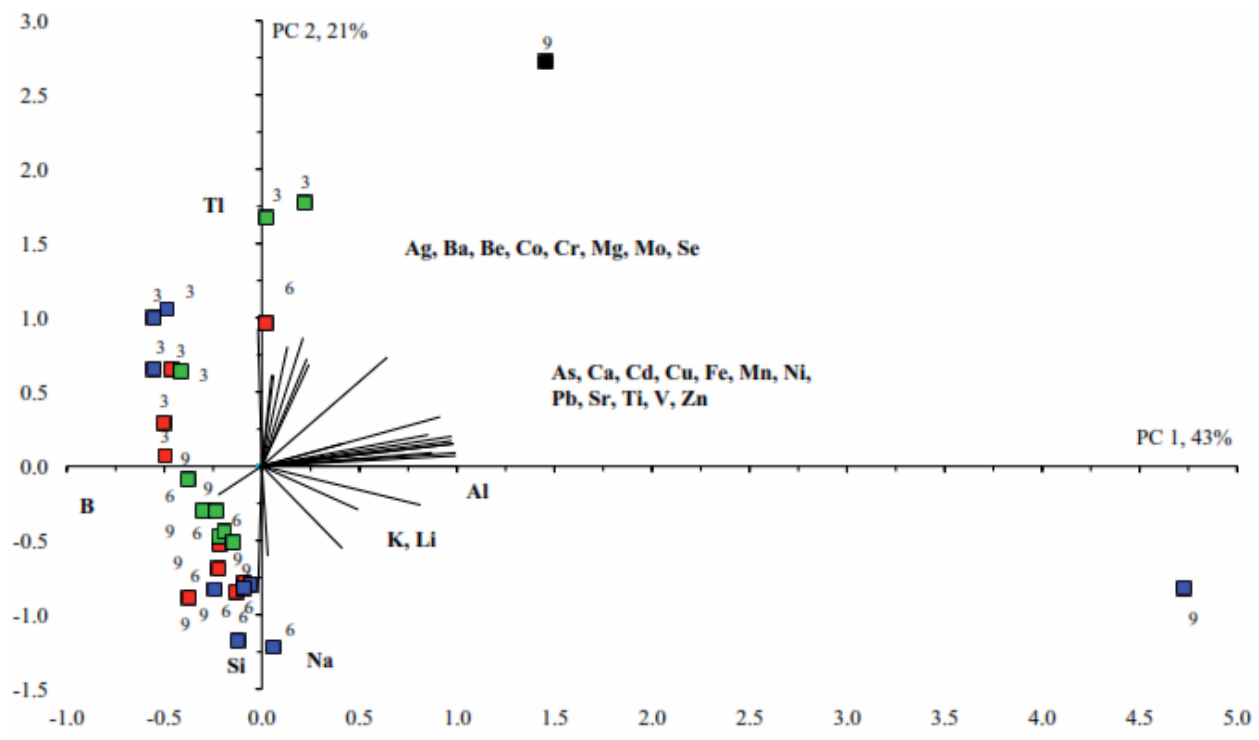

Fig. 8. Principal component analysis of the concentrations of the different elements in the aboveground parts of Ricinus communis L.

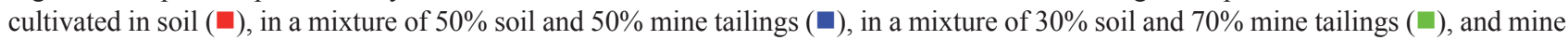
tailings (100\%) (-).Samples were taken at the onset of the experiment (0) and after 3, 6, or 9 months. Principal component 1 (PC1) explained $43 \%$ of the variation and PC2 21\%. 


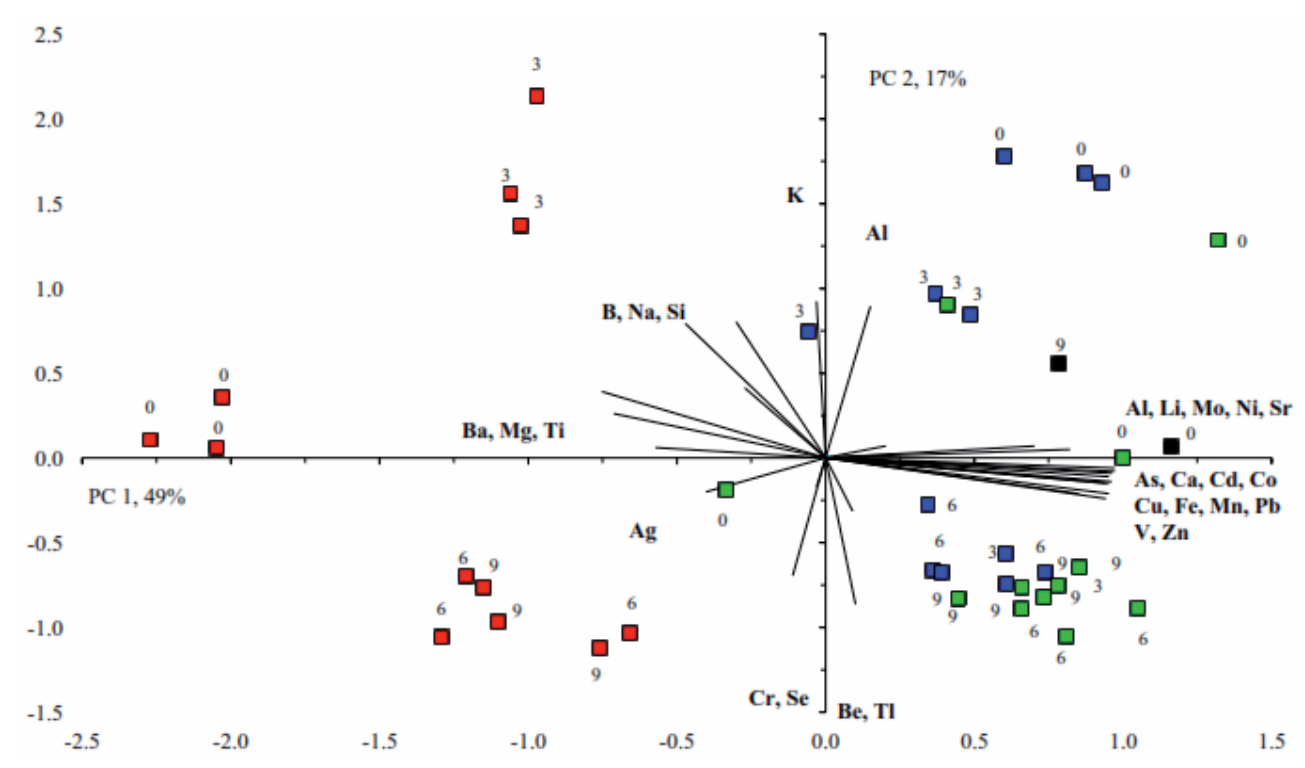

Fig. 9. Principal component analysis of the concentrations of the different elements in uncultivated soil ( $\square$ ), in a mixture of 50\% soil and

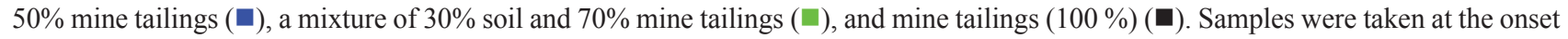
of the experiment (0) and after 3, 6, or 9 months. Principal component 1 (PC1) explained $49 \%$ of the variation and PC2 17\%.

higher than reported in normal soil, i.e., $2 \mathrm{mg} \mathrm{Cd} \mathrm{\textrm {kg } ^ { - 1 }}$ and $200 \mathrm{mg} \mathrm{Pb} \mathrm{kg}^{-1}$ [25]. Concentrations of $\mathrm{Cu}$ in soil are normally $<100 \mathrm{mg} \mathrm{kg}^{-1}$, but reached $1,147 \mathrm{mg} \mathrm{kg}^{-1}$ in the mine tailings used in this study, similar to values reported for the mine tailings in San Luis Potosi $\left(1,154 \mathrm{mg} \mathrm{kg}^{-1}\right)$. Concentrations of As are normally $<50 \mathrm{mg} \mathrm{kg}^{-1}$ soil [26], but they reached $3,473 \mathrm{mg} \mathrm{kg}^{-1}$ in the mine tailings used in this study. In a previous study, however, we found concentrations of $8,420 \mathrm{mg} \mathrm{As} \mathrm{kg}^{-1}$ in mine tailings from San Luis Potosi [24].
Plants can survive contaminated sites by excluding heavy metals or by accumulating them. Some plants accumulate actively metals and some are even called hyper-accumulators, i.e., the concentration of the metal in the shoot is higher than in the root and much higher than in the soil [27]. Ricinus communis did not accumulate heavy metals and excluded them all (i.e., $\mathrm{As}, \mathrm{Co}, \mathrm{Cd}, \mathrm{Cr}, \mathrm{Cu}, \mathrm{Ni}, \mathrm{Pb}$, and $\mathrm{Zn}$ ) from its roots and aboveground parts. Only Mo was accumulated in both the roots and aboveground plant parts and the

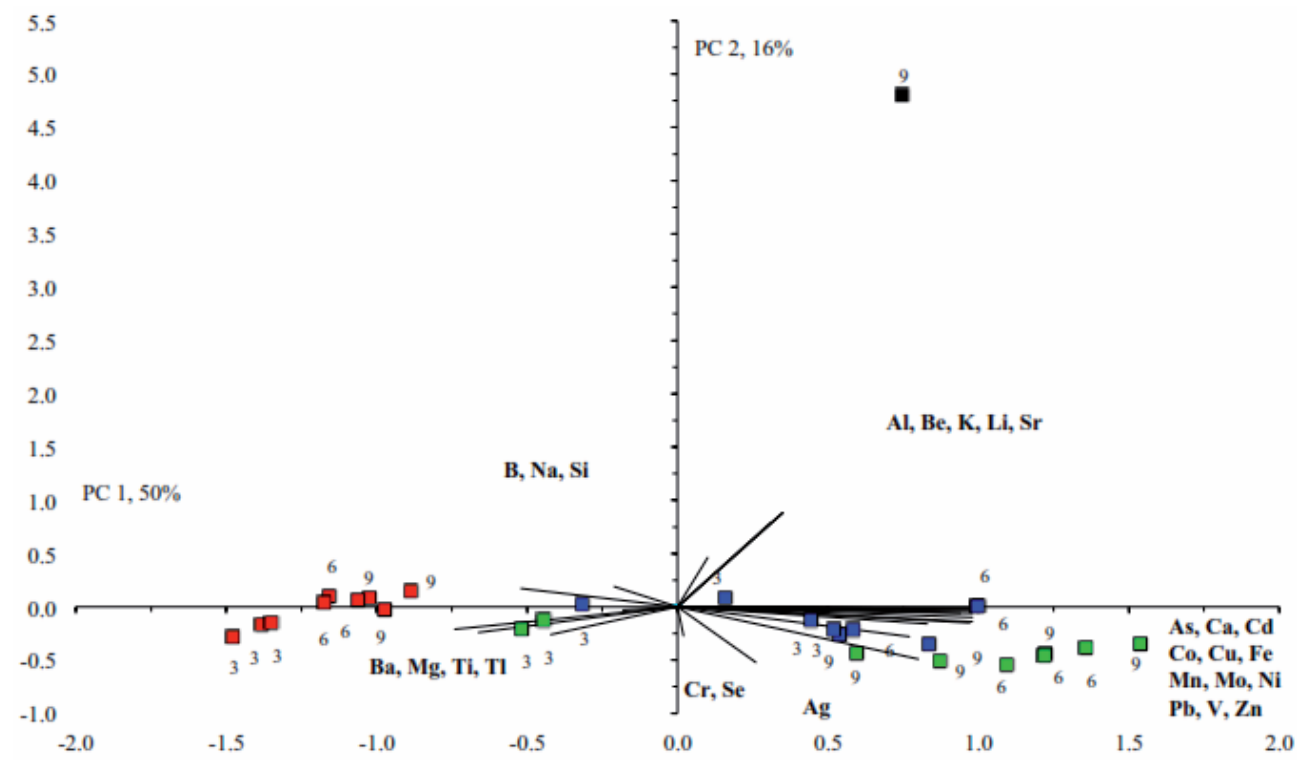

Fig. 10. Principal component analysis of the concentrations of the different elements in the non-rhizosphere when Ricinus communis

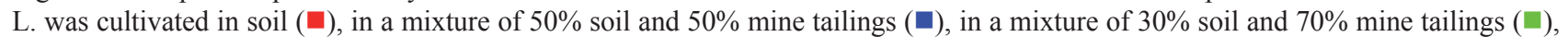
and mine tailings (ם). Samples were taken at the onset of the experiment (0) and after 3, 6, or 9 months. Principal component 1 (PC1) explained $50 \%$ of the variation and PC2 16\%. 
concentration was higher in the latter than in the first. This indicated that $R$. communis was an accumulator of Mo, but not yet a super-accumulator. Molybdenum was presumanly accumulated as it is part of the enzyme nitrate reductase that catalyzes the reduction of nitrates and subsequent formation of amino acids (mainly glutamic acid and glutamine).

Some metals are toxic to plants or plants need them at only low concentrations (e.g., As, $\mathrm{Cd}, \mathrm{Cr}, \mathrm{Cu}$, $\mathrm{Ni}, \mathrm{Pb}$, and $\mathrm{Zn}$ ) [28-29]. Mine tailings, even at 50\%, strongly reduced the number of leaves and reduced leaf area. Toward the end of the experiment, the plants that survived in the mine tailings had leaves, but they were dwarfed severely presumably due to the oxidative stress caused by the high concentration of the heavy metals and lack of water [6]. The mine tailings reduced plant growth, and root length was nearly halved compared to plants cultivated in $30 \%$ soil. Large amounts of heavy metals in soil can increase the concentration of heavy metals in the root system, which inhibit normal plant growth as plant physiology is altered [30-31]. Plants might stimulate defensive mechanisms when they are exposed to $\mathrm{Cd}, \mathrm{Cu}, \mathrm{Zn}, \mathrm{Pb}, \mathrm{Ag}$, and As. They synthesize enzymes that can bind to metal ions via sulfhydryl (-SH) and carboxyl (-COOH) links. Plants also release root exudates - primarily consisting of low molecular weight organic acids - in response to these metal ions in soils. These substances through chelation form complex metal compounds (chelates) avoiding metal intoxification in the plant. These compounds are transported and stored in specialized compartments in the rhizosphere allowing soluble Fe, P, and other micronutrients present in the rhizosphere to be available for plant growth.

Nickel, Mo, $\mathrm{Cu}, \mathrm{Zn}, \mathrm{Mn}, \mathrm{Fe}$, and $\mathrm{B}$ are micronutrients of plants and considered beneficial for plant growth at low concentrations, i.e., as trace elements [32]. These elements are essential for growth and metabolic activity, and found mostly in proteins and as activators of enzymatic reactions. Boron is involved in reproductive growth and found in the membrane and plasmatic wall, while Fe is associated with the production of chlorophyll [33].

The heavy metal tolerance of plants depends not only on the concentration of the contaminants, but also on other factors. For instance, it has been reported that high $\mathrm{Ca}$ concentrations reduces the toxicity of heavy metals. The high $\mathrm{Ca}$ concentration in the mine tailings used in this study might have helped $R$. communis survive in the adverse conditions.

The mine tailings in this study did retain little water, e.g., it was impossible to determine the WHC, and this might have inhibited growth of $R$. communis in the mine tailings. This suggests that mixing soil into the mine tailings did not only reduce the negative effect of the heavy metals, but it also increased water retention (e.g., the WHC was $520 \mathrm{~g} \mathrm{~kg}^{-1}$ in the mixture $30 \%$ soil and $70 \%$ mine tailings). Consequently, vegetating the mine tailings would require some soil to be mixed in the mine tailings, but wind erosion and runoff would be reduced strongly from the vegetated mine tailings, although metal leaching might also be stimulated.

\section{Conclusions}

Ricinus communis grew in $100 \%$ mine tailings although it was strongly inhibited and not all plants survived. Ricinus communis shoots were 19\% smaller and roots $8 \%$ in soil mixed with an equal amount of mine tailings compared to plants cultivated in soil and $33 \%$ and $54 \%$, respectively, when cultivated in mine tailings. Ricinus communis did not accumulate metals, but excluded them to survive with higher concentrations found in the roots than in the aboveground parts. The ratio of $\mathrm{As}, \mathrm{Cd}, \mathrm{Cu}$, and $\mathrm{Pb}$ in the aboveground plant parts to the concentration in soil remained $<0.12$, while that of the roots $<0.25$. Concentrations of heavy metals were generally lower in the rhizosphere than the nonrhizosphere soil of $R$. communis. The As concentration was $35 \%$ lower in the bulk soil than in the rhizosphere. Cultivation of $R$. communis on mine tailings could be used to reduce wind and runoff, but some soil will have to be mixed into the top-layer of the mine tailings to promote water retention (which might stimulate infiltration), reduce metal concentrations, and improve plant growth.

\section{Acknowledgements}

This research was funded by "Centro de Investigación y de Estudios Avanzados del Instituto Politécnico Nacional" (Cinvestav, Mexico). E.G.T. received grant aided support from "Consejo Nacional de Ciencia y de Tecnología" (CONACyT, Mexico). We thank C.E. Márquez-Herrera (UNAM, Mexico) for help with the heavy metal analysis and M.L. Marín-García (CIIEMAD-IPN, Mexico) for mine tailings sampling and cultivation of Ricinus communis. We thank J.I. Hernández (UNSIJ, México) for elaborating upon a map of the study area.

\section{References}

1. MONTERROSO C., RODRÍGUEZ F., CHAVES R., DIEZ J., BECERRA-CASTRO C.C., KIDD P.S., MACIAS F. Heavy metal distribution in mine-soils and plants growing in a $\mathrm{Pb} / \mathrm{Zn}$-mining area in NW Spain. Appl. Geochem. 44, 3, 2014.

2. SECRETARÍA DE ECONOMÍA. Reporte de coyuntura de la minería 2011. Available online at http://www.economia. gob.mx (accessed on 30 March 2013).

3. VÁSQUEZ-MURRIETA, M.S., MIGUELESGARDUNNO I., FRANCO-HERNANDEZ O., GOVAERTS B., DENDOOVEN L. C and N mineralization and microbial biomass in heavy-metal contaminated soil. Eur. J. Soil. Biol. 42 (2), 89, 2006. 
4. HERNÁNDEZ-HERNÁNDEZ A., LÓPEZ-LUNA J., GONZÁLEZ-TERREROS E. Heavy metals quantification in community soils impacted by mining activities in the northern mountains of Oaxaca, México. Environ. Sci. Ind. J. 7, 343, 2012.

5. PHAENARK C., POKETHITIYOOK P., KRUATRACHUE M., NGERNSANSARUAY C. Cd and $\mathrm{Zn}$ accumulation in plants from the Padaeng zinc mine area. Int. J. Phytoremediat. 11 (5), 479, 2009.

6. KUMAR G.H., KUMARI J.P. Heavy metal lead influative toxicity and its assessment in phytoremediating plants a review. Water Air Soil Poll. 226 (10), 324, 2015.

7. GIORDANI C., CECCHI S., ZANCHI C. Phytoremediation of soil polluted by nickel using agricultural crops. Environ. Manage. 36 (5), 675, 2005.

8. MELO E.E.C., GUILHERME L.R.G., NASCIMENTO W.A.C., PENHA, H.G.V. Availability and accumulation of arsenic in oilseeds grown in contaminated soils. Water Air Soil Poll. 223 (1), 233, 2012

9. WEERADEJ M., PRAYAD P., MALEEYA K., PHANWIMOL T., RATTANAWAT C. Phytostabilization of a $\mathrm{Pb}$-contaminated mine tailing by various tree species in pot and field trial experiments. Int. J. Phytoremediat. 14 (9), 925, 2012.

10. ORTEGA-LARROCEA M.P., XOCONOSTLE-CÁZARES B., MALDONADO-MENDOZA I.E., CARRILLOGONZÁLEZ R., HERNÁNDEZ-HERNÁNDEZ J., DÍAZ-GARDUÑO M., LÓPEZ-MEYER M.M., GÓMEZFLORES L., GONZÁLEZ-CHÁVEZ C.A. Plant and fungal biodiversity from metal mine wastes under remediation at Zimapán, Hidalgo, Mexico. Environ Pollut. 158 (5), 1922, 2010.

11. LIM T.K. Ricinus communis. In Edible Medicinal And Non-Medicinal Plants: Fruits, 1st ed.; Springer Science and Business Media B.V., Heidelberger platz 3, d-14197 Berlin, Germany, 2, 484, 2012.

12. LAVANYA C., MURTHY I.Y.L.N., NAGARAJ G., MUKTA N. Prospects of castor (Ricinus communis L.) genotypes for biodiesel production in India. Biomass Bioenerg. 39, 204, 2012.

13. PERDOMO F.A., ACOSTA-OSORIO A.A., HERRERA G., VASCO-LEAL J.S., MOSQUERA-ARTAMONOV J.D., MILLAN-MALO B., RODRIGUEZ-GARCÍA M.D. Physicochemical characterization of seven Mexican Ricinus communis L. seeds and oil contents. Biomass Bioenerg. 48, 17, 2013.

14. JABEEN S., TAHIR S.M., KHAN S., QASIM H.M. Determination of major and trace elements in ten important folk therapeutic plants of Haripur basin, Pakistan. J. Med. Plants Res. 4 (7), 559, 2010.

15. BODA R.K., PRASAD M.N.V. Ricinus communis L. (Castor bean), a potential multi-purpose environmental crop for improved and integrated phytoremediation. The Euro. Biotech. Journal. 1 (2), 101, 2017.

16. KNOTHE G.H. Biodiesel and its properties. In Industrial Oil Crops, McKeon, T.A., Hayes, D.G., Hildebrand, D.F., Weselake, R.J., Eds. Urbana, IL: AOCS Press. 15, 2016.

17. ALGUACIL M.M., TORRECILLAS E., HERNÁNDEZ G., ROLDÁN A. Changes in the diversity of soil arbuscular mycorrhizal fungi after cultivation for biofuel production in a Guantanamo (Cuba) tropical System. Plos ONE. 7 (4), e34887, 2012.

18. BAUDDH K., SINGH K., BHASKAR S., SINGH R.P. Ricinus communis: A robust plant for bio-energy and phytoremediation of toxic metals from contaminated soil. Ecol. Eng. 84, 640, 2015.

19. BELLINI G., SUMNER M.E., RADCLIFFE D.E., QAFOKU N.P. Anion transport through columns of highly weathered acid soil: Adsorption and retardation. Soil Sci. Soc. Am. J. 60 (1), 132, 1996.

20. CLEMENSSON L., PERSSON H. Effects of freezing on rhizosphere and root nutrient content using two soil sampling methods. Plant Soil. 139 (1), 39, 1992.

21. AGUILAR-CHÁVEZ A., DÍAZ-ROJAS M., CÁRDENASAQUINO M.D., DENDOOVEN L., LUNA-GUIDO G.M. Greenhouse gas emissions from a wastewater sludgeamended soil cultivated with wheat (Triticum spp. L.) as affected by different application rates of charcoal. Soil Biol. Biochem. 52, 90, 2012.

22. SAS INSTITUTE. Statistic Guide for Personal Computers. Version 6.0. (eds.). SAS Institute, Inc., Cary. 1989.

23. WU X.H., ZHANG H.S., GANG L., LIU X.C., QIN P. Ameliorative effect of castor bean (Ricinus communis L.) planting on physicochemical and biological properties of seashore saline soil. Ecol. Eng. 38, 97, 2012.

24. FRANCO-HERNÁNDEZ M.O., VASQUEZ-MURRIETA M.S., PATIÑO-SICILIANO A., DENDOOVEN L. Heavy metals concentration in plants growing on mine tailings in Central México. Bioresource Technol. 101 (11), 3864, 2010.

25. LINDSAY W L. Chemical Equilibria in Soil. Wiley Interscience, New York, USA,. Pp. 315-326, 1979.

26. MITCHELL P., BARR D. The nature and significance of public exposure to arsenic a review of its relevance to South-West England. Environ. Geochem. Hlth. 17 (2), 57, 1995.

27. OLOWU R.A., ADEWUYI G.O., ONIPEDE O.J., LAWAL O.A., SUNDAY O.M. Concentration of heavy metals in root, stem and leaves of Acalypha indica and Panicum maximum Jacq from three major dumpsites in Ibadan metropolis, South West Nigeria. Am. J. Chem. 5 (1), 40, 2015.

28. SAGHALI M., HOSEINI S.M., HOSSEINI S.A., BAQRAF R. Determination of heavy metal $(\mathrm{Zn}, \mathrm{Pb}, \mathrm{Cd}$ and $\mathrm{Cr}$ ) concentration in benthic fauna tissues collected from the southeast Caspian Sea, Iran. B. Environ. Contam. Tox. 92 (1), 57, 2014.

29. SANCHEZ-LÓPEZ A.S., CARRILLO-GONZÁLEZ R., GONZÁLEZ-CHÁVEZ M.D.A., ROSAS-SAITO G.H., VANGRONSVELD J. Phytobarriers: Plants capture particles containing potentially toxic elements originating from mine tailings in semiarid regions. Environ. Pollut. 205, 33, 2015.

30. MASSAS I., KALIVAS D., EHALIOTIS C., GASPARATOS D. Total and available heavy metal concentrations in soils of Thriassio plain (Greece) and assessment of soil pollution indexes. Environ. Monit. Assess. 185 (8), 6751, 2013.

31. WANG S., ZHAO Y., GUO J., ZHOU L. Effects of Cd, $\mathrm{Cu}$ and $\mathrm{Zn}$ on Ricinus communis L. Growing in single elemento $\mathrm{r}$ co-contaminated soils: Pot experiments. Ecol. Eng. 90, 347, 2016.

32. EPSTEIN E., BLOOM J. Inorganic Components of Plants. In Mineral Nutrition of Plants: Principles and Perspectives, $2^{\text {nd }}$. Sunderland, Sinauer Associates. Sunderland, Massachusetts, USA, 41, 2004.

33. KIRKBY E., RÖMHELD V. Micronutrients in Plant Physiology: Functions, Up-take and Mobility. Proceedings 543, The International Fertilizer Society, P.O. Box, York, United Kingdom, 52, 2007. 